\title{
Snail Shells Adsorbent for Copper Removal from Aqueous Solutions and the Production of Valuable Compounds
}

\author{
Redouane Ouafi $\mathbb{D}^{1},{ }^{1}$ Meryem Asri, ${ }^{2}$ Anass Omor, ${ }^{1}$ Mustapha Taleb, ${ }^{1}$ and Zakia Rais ${ }^{1}$ \\ ${ }^{1}$ Engineering Laboratory of Organometallic Molecular Materials and Environment, Faculty of Science Dhar El Mahraz, \\ Sidi Mohamed Ben Abdellah University, Fez, Morocco \\ ${ }^{2}$ Microbial Biotechnology and Bioactive Molecules Laboratory, Faculty of Sciences and Techniques, \\ Sidi Mohammed Ben Abdellah University, Fez, Morocco \\ Correspondence should be addressed to Redouane Ouafi; redouane.ouafi@usmba.ac.ma
}

Received 6 May 2021; Revised 16 August 2021; Accepted 8 September 2021; Published 23 September 2021

Academic Editor: Shafaqat Ali

Copyright (c) 2021 Redouane Ouafi et al. This is an open access article distributed under the Creative Commons Attribution License, which permits unrestricted use, distribution, and reproduction in any medium, provided the original work is properly cited.

\begin{abstract}
This research explored the efficiency of snail shells powder (SSP) for $\mathrm{Cu}$ (II) removal from aqueous solutions and the production of valuable compounds from the residual product. To confirm its chemical and mineral components, the material was characterized by different instrumental techniques. The effects of experimental parameters such as the $\mathrm{pH}$ of the solution, the effect of SSP dose, particle size, and initial concentration of $\mathrm{Cu}$ (II) on the removal process were studied. The removal of $\mathrm{Cu}$ (II) was reasonably fast to be completed within a time frame of $90 \mathrm{~min}$. The kinetics following the pseudo-second-order model $\left(R^{2}=0.979\right)$ were better compared to the pseudo-first-order model $\left(R^{2}=0.896\right)$. The increase in $\mathrm{pH}$ values leads to an increase in the amount of $\mathrm{Cu}(\mathrm{II})$ adsorbed. Afterward, the adsorption capacity reaches stability at $\mathrm{pH}$ near 7 . The maximum $\mathrm{Cu}(\mathrm{II})$ removal occurred with a mass of $8 \mathrm{~g} \cdot \mathrm{L}^{-1}$ and a particle size of $300 \mu \mathrm{m}$. This particle size presents approximately $44.5 \%$ of SSP particles, which is the largest proportion of the sample as shown by particle size analysis. The adsorption isotherm was well described by Langmuir and Freundlich equations. The thermodynamic parameters values showed that the $\mathrm{Cu}(\mathrm{II})$ adsorption was a spontaneous and exothermic process. Furthermore, with the presence of $\mathrm{CaCO}_{3}$, the precipitation of $\mathrm{Cu}(\mathrm{II})$ in the form of posnjakite occurred with a high $\mathrm{Cu}(\mathrm{II})$ removal rate close to $99 \%$. The residual SSP was used for the production of valuable compounds through the thermal decomposition process at various temperatures.
\end{abstract}

\section{Introduction}

Their persistence against chemical and biological decomposition and their great environmental mobility characterize heavy metals. They exhibit an extreme bioaccumulation tendency in the food chain, thus exposing human and environmental health to slow but certain poisoning [1]. Heavy metals such as cobalt $(\mathrm{Co})$, copper $(\mathrm{Cu})$, chromium $(\mathrm{Cr})$, iron $(\mathrm{Fe})$, magnesium $(\mathrm{Mg})$, manganese $(\mathrm{Mn})$, molybdenum $(\mathrm{Mo})$, nickel $(\mathrm{Ni})$, selenium $(\mathrm{Se})$, and zinc $(\mathrm{Zn})$ are essential nutrients [2]. They are involved in very low concentrations in various biochemical and physiological functions necessary to maintain the metabolism of the human body, plants, and animals [3]. However, at high concentrations, these micronutrients can cause various effects on human health, including cardiovascular disease, developmental abnormalities, nervous system damage, neurological disorders, diabetes, reduced growth, hematological and immunological disorders, various types of cancer, and, in extreme cases, death $[4,5]$.

$\mathrm{Cu}$ enzymes are involved in several metabolic processes, such as the use of oxygen during cell respiration and energy utilization. They also participate in the production of essential compounds such as the diverse proteins of the skeleton's connective tissues and blood vessels. The adult human body was estimated to contain from 50 to $120 \mathrm{mg}$ of $\mathrm{Cu}$ [2]. $\mathrm{Cu}$ is one of the most valuable and commonly used metals in many industrial applications, such as metal surface treatment, electroplating, and foundries [6,7]. It is a toxic metal even at low concentrations and is generally found at 
high concentrations in wastewater. Therefore, $\mathrm{Cu}$-contaminated wastewater must be treated before being discharged into the environment. New easy-to-implement technologies deserve special attention. Indeed, adsorption using low-cost natural material to remove heavy metals from wastewater has proven its worth as a promising alternative to traditional physicochemical methods. These available and inexpensive materials can be involved in an effective and economically attractive remediation process [8]. In recent decades, a growing interest in low-cost adsorbents has been observed. Due to their many advantages, they have been extensively used for heavy metals and removal of other pollutants $[9,10]$. Therefore, various materials have been investigated as adsorbents to remove different types of pollutants from aqueous solutions [11-13]. These materials include chitosan $[14,15]$, bentonite [16], almond shell [17], pistachio wood [18], Ballota biomass [19], chicken eggshell [20], and oyster shell [21].

In common with the incessant search for cheaper, feasible, and effective products for removal of heavy metals and environmental restoration, the ability of the snail shells for $\mathrm{Cu}$ (II) removal from contaminated aqueous solutions was explored in the present research. Snail shells are an abundant, inexpensive, and natural waste. Snails are appreciated as gastronomic food in several countries including Morocco. They provide an easily harvested source of protein for local communities, discarding the shells as waste [22]. Using these shells as an adsorbent turns waste material into a potentially useful resource. The characterization of the product was carried out by using scanning electron microscope (SEM), energy dispersive X-ray spectroscopy (EDX), Fourier transform infrared spectroscopy (FTIR), the point of zero charge (pHpzc), and X-ray diffraction analysis (DRX). The influence of $\mathrm{pH}$ of solutions, SSP dose, particle size, and initial $\mathrm{Cu}$ (II) concentration on the $\mathrm{Cu}$ (II) removal efficiency by SSP was studied through the batch method. The kinetic studies and mechanism adsorption between $\mathrm{Cu}$ (II) and SSP were discussed. The isotherm models and thermodynamic parameters were investigated. The production of valuable products in a single simple operation was also examined.

\section{Materials and Methods}

2.1. Adsorbent Material Preparation. The snail shells were collected from ambulant merchants in Fez, Morocco. They were washed several times with tap water and then ovendried at $80^{\circ} \mathrm{C}$ for 2 hours. The shells were crushed in an agate mortar; impurities such as the flesh were removed. They were finally washed several times with distilled water and dried in an oven at $100^{\circ} \mathrm{C}$ for 12 hours. The above-dried shells were grounded to a fine powder. The resulting SSP was sieved through a range of sieves. The different resulting powders were collected and used for experimental purposes.

2.2. Aqueous Metal Ions Solutions Preparation. The solutions of $\mathrm{Cu}(\mathrm{II})$ were prepared by dissolving $3.927 \mathrm{~g}$ of $\mathrm{CuSO}_{4} \cdot 5 \mathrm{H}_{2} \mathrm{O}$ in deionized water (Barnstead EASYpure II) to achieve a concentration of $1000 \mathrm{mg} \cdot \mathrm{L}^{-1}$. Experimental solutions of the desired concentrations of metal ions were prepared by diluting the stock solution in deionized water. The $\mathrm{pH}$ of the solutions was adjusted using $0.1 \mathrm{~N} \mathrm{HCl}$ and $0.1 \mathrm{~N} \mathrm{NaOH}$ to achieve a $\mathrm{pH}$ value ranging from 2 to 8 ; measurements were performed using a Hanna $\mathrm{pH}$-meter model HI 2221. All reagents were AR-grade reagents obtained from Sigma-Aldrich Chemical Company.

\subsection{Physicochemical Characterization}

2.3.1. Fourier Transform Infrared Spectroscopy. Fourier transform infrared spectroscopy (FTIR) analysis was recorded using a Bruker FTIR spectrophotometer model Vertex 70 (Germany) in the range of $400-4000 \mathrm{~cm}^{-1}$, using ATR mode; 16 scans were accumulated at a resolution of $4 \mathrm{~cm}^{-1}$.

2.3.2. Scanning Electron Microscopy. Morphological and elemental composition analyses were carried out using a JEOL JSM IT500HR (Japan) scanning electron microscope equipped with an energy dispersive X-ray spectroscopy (EDX) operated under high vacuum mode, a landing voltage (HV) of $10-12 \mathrm{kV}$, and a working distance (WD) of $10.5 \mathrm{~mm}$.

2.3.3. X-Ray Diffraction Analysis. X-ray diffraction (XRD) analysis was obtained using a Panalytical X'Pert Pro X-ray diffractometer (Netherlands) equipped with a $\mathrm{Cu}-\mathrm{K} \alpha$ monochromatic source $(1.54 \AA)$, operating at a voltage of $40 \mathrm{kV}$ and a filament current of $40 \mathrm{~mA}$. The diffraction pattern was recorded from $10^{\circ}$ to $90^{\circ}(2 \theta)$ with continuous scanning at a step size of $0.017(2 \theta)$ and a scan step time of $45.08 \mathrm{~s}$.

2.3.4. Thermogravimetric Analysis. Thermogravimetric Analysis (TGA) and Differential Thermal Analysis (DTA) of the SSP were performed using a SHIMADZU DTG-60H (Japan) instrument under air atmosphere, with a heating rate of $20^{\circ} \mathrm{C} / \mathrm{min}$ from 27 to $1000^{\circ} \mathrm{C}$. The sample mass introduced was $27.40 \mathrm{mg}$.

2.3.5. Particle Size Analysis. The particle size analysis was conducted using an AS 200 RETSCH analytical sieving machine (Germany) through a series of sieves in accordance with ISO3310-1. A sample of $200 \mathrm{~g}$ of SSP was removed and sieved for 40 minutes at an amplitude of $1.8 \mathrm{~mm}$; the resulting refusal is collected and weighed.

2.3.6. Specific Surface Area. The specific surface area $\left(\mathrm{S}_{\mathrm{BET}}\right)$ was measured using a Gemini VII 2390t surface area analyzer, Micromeritics Instruments Corp. (United States). The values $S_{B E T}$ of SPP were determined from the $\mathrm{N}_{2}$ adsorption isotherms by applying the Brunauer-Emmett-Teller (BET) equation at a relative pressure range of $0.05-0.30$ and an average area per molecule of $\mathrm{N}_{2}$ in a completed monolayer $\left(\sigma_{\mathrm{m}}\right)$ of $0.1620 \mathrm{~nm}^{2}$. 
2.3.7. Point of Zero Charge. The point of zero charge (pHpzc) is an important feature that determines the $\mathrm{pH}$ at which the surface of the adsorbent has net electrical neutrality. At this value, the acidic or basic functional groups no longer contribute to the $\mathrm{pH}$ of the solution. The adsorption of the cations will be more favorable at $\mathrm{pH}$ higher than pHpzc. The pHpzc of SSP was determined by the solid addition method in our previous study [23].

2.4. Batch Adsorption Experiments. The experiments in batch modes were carried out by bringing into contact in $100 \mathrm{~mL}$ flasks a determined quantity of adsorbents, with $50 \mathrm{~mL}$ of a synthetic solution of the metal ion at the desired concentration. The flasks were stirred in a shaker incubator (Cleaver Scientific Ltd.) at a constant speed and temperature of $25^{\circ} \mathrm{C}$. After sufficient contact time, allowing the adsorption to reach equilibrium, the solutions were collected and the supernatant was separated by centrifugation at $4000 \mathrm{rpm}$ for $5 \mathrm{~min}$ using Hettich Universal 320 centrifuge. Afterward, the $\mathrm{Cu}$ (II) concentration in the supernatant was determined using inductively coupled plasma-atomic emission spectroscopy (ICP-AES), model Activa from Horiba Jobin-Yvon (French). The solid residue collected was dried at atmospheric conditions for phase identification. The amount of heavy metal ions sequestrated $q_{\mathrm{e}}\left(\mathrm{mg}^{\mathrm{g}} \mathrm{g}^{-1}\right)$ was calculated by the following expression $[24,25]$ :

$$
q_{e}=\frac{\left(C_{0}-C_{e}\right) V}{m}
$$

The $\mathrm{Cu}(\mathrm{II})$ elimination rate $R(\%)$ was defined by

$$
R(\%)=\frac{\left(C_{0}-C_{e}\right)}{C_{0}} \times 100,
$$

where $C_{0}$ is the initial metal ion concentration in the solution $\left(\mathrm{mg} \cdot \mathrm{L}^{-1}\right), C_{\mathrm{e}}$ is the residual metal ion concentration measured at equilibrium $\left(\mathrm{mg} \cdot \mathrm{L}^{-1}\right), m$ is the mass of adsorbents introduced in solution (g), and $V$ is the volume of the $\mathrm{Cu}$ (II) solution (L).

2.5. Kinetic Study. The kinetic study was carried out by using a method similar to batch adsorption experiments. After specified time intervals, the solutions of the flasks were collected and the supernatant was separated by centrifugation. The amount of metal ions adsorbed at time $t, q_{\mathrm{t}}$ $\left(\mathrm{mg}^{-1} \mathrm{~g}^{-1}\right.$, was calculated from the following expression:

$$
q_{t}=\frac{\left(C_{0}-C_{t}\right) V}{m}
$$

where $C_{0}$ and $C_{\mathrm{t}}$ are the initial metal ion concentration and concentration at a defined time $\left(\mathrm{mg} \cdot \mathrm{L}^{-1}\right), V$ is the solution volume $(\mathrm{L})$, and $m$ is the mass of the adsorbent $(\mathrm{g})$.

In this study, pseudo-first-order model (PFO) [26], pseudo-second-order model (PSO) [27], and Elovich [28] were employed to analyze the adsorption kinetics of $\mathrm{Cu}$ (II) by SSP.

The PFO equation can be expressed in the following linear form:

$$
\ln \left(q_{e}-q_{t}\right)=\ln \left(q_{e}\right)-k_{1} t
$$

The PSO equation can be expressed in the following linear form:

$$
\frac{t}{q_{t}}=\frac{1}{k_{2} q_{e}^{2}}+\left(\frac{1}{q_{e}}\right) t
$$

where $q_{\mathrm{t}}$ is the amount of adsorbate adsorbed at time $t$ $\left(\mathrm{mg} \cdot \mathrm{g}^{-1}\right)$ calculated using equation (3), $q_{\mathrm{e}}$ is the equilibrium adsorption capacity $\left(\mathrm{mg} \cdot \mathrm{g}^{-1}\right), k_{1}$ is the pseudo-first-order rate constant $\left(\mathrm{min}^{-1}\right), k_{2}\left(\mathrm{~g} \cdot \mathrm{mg}^{-1} \cdot \mathrm{min}^{-1}\right)$ is the pseudosecond-order rate constant, and $t$ is the contact time (min).

The plot of $\ln \left(q_{\mathrm{e}}-q_{\mathrm{t}}\right)$ versus $t$ gives a straight line for the pseudo-first adsorption kinetics, which allows the determination of $k_{1}$ from the slope and $q_{\mathrm{e}}$ from the $y$-intercept. For the pseudo-second-order adsorption kinetics, $q_{\mathrm{e}}$ and $k_{2}$ can be determined from the intercept of the linearized plot of $t / q_{\mathrm{t}}$ versus $t$.

The Elovich equation can be expressed mathematically as follows:

$$
q_{t}=\frac{1}{\beta} \ln (t)+\frac{1}{\beta} \ln (\alpha \beta),
$$

where $\alpha$ is the initial rate constant $\left(\mathrm{mg} \cdot \mathrm{g}^{-1} \cdot \mathrm{min}^{-1}\right)$ and $\beta$ $\left(\mathrm{mg} \cdot \mathrm{g}^{-1}\right)$ is the desorption constant at time $t$. The parameters $\alpha$ and $\beta$ can be calculated from the slope $(1 / \beta)$ and intercept $(1 / \beta) \ln (\alpha \beta)$ of the linear plot of $q_{\mathrm{t}}$ versus $\ln (t)$ with $\beta=1$ / slope and $\alpha=\exp ($ intercept $\times \beta) / \beta$.

\subsection{Effects of Experimental Parameters on Cu(II) Removal}

2.6.1. Effect of $p H$. The effect of $\mathrm{pH}$ on the adsorption process was examined maintaining the described batch adsorption experiments and varying the $\mathrm{pH}$ of the solution from 2 to 8 . The initial $\mathrm{Cu}(\mathrm{II})$ concentration was $100 \mathrm{mg} \cdot \mathrm{L}^{-1}$ and the mass of the adsorbent was $0.4 \mathrm{~g}$. The mixture was shaken for $90 \mathrm{~min}$ at an agitation speed equal to $200 \mathrm{rpm}$ and a temperature equal to $25^{\circ} \mathrm{C}$.

2.6.2. Effect of Adsorbent Dose. The effect of adsorbent dose was determined by maintaining the described batch adsorption experiments and varying the amount of SSP from 0.05 to $1.2 \mathrm{mg}$. The initial $\mathrm{Cu}(\mathrm{II})$ concentration was $100 \mathrm{mg} \cdot \mathrm{L}^{-1}$ and $\mathrm{pH}$ was 4.7 . The mixture was shaken for $90 \mathrm{~min}$ at an agitation speed equal to $200 \mathrm{rpm}$ and a temperature equal to $25^{\circ} \mathrm{C}$.

2.6.3. Effect of Particle Size. The effect of particle size of SSP was examined through different particle sizes from 50 to $800 \mu \mathrm{m}$. The initial Cu(II) concentration was $100 \mathrm{mg} \cdot \mathrm{L}^{-1}$ and the mass of the adsorbent was $0.4 \mathrm{~g}$. The mixture was shaken for $90 \mathrm{~min}$ at an agitation speed equal to $200 \mathrm{rpm}$, a temperature equal to $25^{\circ} \mathrm{C}$, and a $\mathrm{pH}$ equal to 4.7 .

2.6.4. Effect of Initial Metal Concentration. The effect of metal concentration on $\mathrm{Cu}(\mathrm{II})$ elimination rate was 
examined by varying the $\mathrm{Cu}(\mathrm{II})$ concentration from 50 to $500 \mathrm{mg} \cdot \mathrm{L}^{-1}$. The adsorbent mass was $0.4 \mathrm{~g}$ and the particle size was $300 \mu \mathrm{m}$. The mixture was shaken for $90 \mathrm{~min}$ at an agitation speed equal $200 \mathrm{rpm}$, a temperature equal to $25^{\circ} \mathrm{C}$, and a $\mathrm{pH}$ equal to 4.7 .

2.7. Equilibrium Isotherm. Langmuir [29] and Freundlich [30] models were used to investigate and describe adsorption removal processes. The models were used to describe the distribution of metal ions between liquid and solid phases. The nonlinear method was used to calculate the parameters of the isotherms using the original form of the equation [31]. The isotherms models were fitted through LevenbergMarquardt algorithm using OriginPro software.

2.8. Thermodynamic Study. The thermodynamic parameters were investigated at $298,313,323$, and $333 \mathrm{~K}$. The standard free energy change $(\Delta G \underline{0})$, standard enthalpy change $(\Delta H \underline{0})$, and standard entropy change $(\Delta S \underline{S})$ were calculated according to the following equations [24]:

$$
\begin{gathered}
\Delta^{G^{\circ}}=-R T \ln K_{c}, \\
\Delta^{G^{\circ}}=\Delta^{H^{\circ}}-T \Delta^{S^{\circ}}, \\
\ln K_{c}=-\frac{\Delta^{H^{\circ}}}{R} \frac{1}{T}+\frac{\Delta^{S^{\circ}}}{R},
\end{gathered}
$$

where $R$ is the universal gas constant $\left(8.3144 \mathrm{~J} \cdot \mathrm{mol}^{-1} \cdot \mathrm{K}^{-1}\right), T$ is the absolute temperature in Kelvin $(\mathrm{K})$, and $K_{\mathrm{c}}$ is the equilibrium constant.

According to previous works, the equilibrium constant $K_{\mathrm{c}}$ must be dimensionless and could be derived from the Langmuir constant using the following equation [32-34]:

$$
K_{c}=63.54 \times 55.5 \times 1000 \times K_{L},
$$

where $55.5\left(\mathrm{~mol} \cdot \mathrm{L}^{-1}\right)$ is the number of moles of pure water per litre, $63.54\left(\mathrm{~g} \cdot \mathrm{mol}^{-1}\right)$ is the molecular weight of $\mathrm{Cu}, 1000$ $\left(\mathrm{g} \cdot \mathrm{L}^{-1}\right)$ is the value of the water density, and $K_{\mathrm{L}}$ is the Langmuir constant $\left(\mathrm{L} \cdot \mathrm{mg}^{-1}\right)$.

2.9. Thermal Treatment of the Residual Product. The residual product obtained after the $\mathrm{Cu}(\mathrm{II})$ removal by SSP was used as a precursor to produce mixed oxide. A simple one-step thermal decomposition method was used. For this purpose, $20 \mathrm{~g}$ of the residual product was calcined at 700,900, and $1000^{\circ} \mathrm{C}$ for $120 \mathrm{~min}$ under an air atmosphere. The thermal treatment was performed with a Nabertherm P330 muffle furnace.

\section{Results and Discussion}

3.1. SEM Analysis. The surface morphologies of SSP before and after the $\mathrm{Cu}(\mathrm{II})$ treatment are shown in Figure 1. The SEM images in Figure 1(a) indicate that the surface of SSP consists of condensed agglomerates made up of small particles. Furthermore, the SSP exhibits heterogeneous surface morphology. These results are in accordance with those found in previous studies [24, 35, 36].

Clear differences in raw SSP and $\mathrm{Cu}(\mathrm{II})$ loaded SSP surface morphology can be observed from the SEM images. Indeed, the SEM images in Figure 1(b) show the emergence of secondary solids on the surface in the form of thin platelets. These aggregates indicate that surface precipitation may occur during the reaction, leading to the presence of structures whose morphology was matching on the study observed from the synthesized posnjakite particles [37, 38]. These observations were further strengthened by the EDX results. As indicated in Figure 1(c), the elemental compositions of raw SSP are carbon $(\mathrm{C})$, oxygen $(\mathrm{O})$, and calcium (Ca). The existence of $\mathrm{Cu}$ on the $\mathrm{Cu}$ (II) loaded SSP surface is shown evidently in Figure 1(d). This result shows the accumulation of $\mathrm{Cu}$ on the surface of SPP.

$\mathrm{S}_{\mathrm{BET}}$ of the SSP determined using the BET method was $0.72 \mathrm{~m}^{2} \cdot \mathrm{g}^{-1}$. The SSP was classified as a nonporous material in accordance with IUPAC classification [39]. In this case, the adsorption ability of the SSP is presumably not impacted by $S_{\text {BET. }}$. Several researchers found that the $\mathrm{CaCO}_{3}$-rich adsorbent has a low $\mathrm{S}_{\mathrm{BET}}$ value. Lertwattanaruk et al. [40] reported that the surface area of a ground short-necked clam, green mussel, and cockle shell powder was determined as being $0.82,0.61$, and $0.82 \mathrm{~m}^{2} \cdot \mathrm{g}^{-1}$, respectively. Van et al. [41] reported a specific surface area of $1.45 \mathrm{~m}^{2} \cdot \mathrm{g}^{-1}$ for biogenic freshwater mussel shells. Also, Lim and Aris [42] found a specific surface area of $0.21 \mathrm{~m}^{2} \cdot \mathrm{g}^{-1}$ for dead calcareous skeletons.

3.2. FTIR Analysis. The infrared spectra of raw SSP (Figure 2(a)) indicated the presence of the characteristic functional groups of the carbonate ions $\left(\mathrm{CO}_{3}{ }^{2-}\right)$, identified by the absorption bonds of $1447.40 \mathrm{~cm}^{-1}, 1082.62 \mathrm{~cm}^{-1}$, $854.19 \mathrm{~cm}^{-1}$, and $712.33 \mathrm{~cm}^{-1}$. The double peak at $699.60 \mathrm{~cm}^{-1}$ and $712.33 \mathrm{~cm}^{-1}$ and the peak at $1082.62 \mathrm{~cm}^{-1}$ are characteristic of the aragonite structure. A FTIR spectral detailed analysis of raw SSP was carried out in our previous study [23]. Those results are consistent with previous research $[43,44]$.

The infrared spectra of SSP after reaction revealed a decrease in the relative intensities of most of the absorption bands of $\mathrm{CaCO}_{3}$, especially those located at $1447.40 \mathrm{~cm}^{-1}$, $854.19 \mathrm{~cm}^{-1}, 712.33 \mathrm{~cm}^{-1}$, and $699.60 \mathrm{~cm}^{-1}$. In addition, new bands appeared at $1116.68 \mathrm{~cm}^{-1}, 800.38 \mathrm{~cm}^{-1}, 603.66 \mathrm{~cm}^{-1}$, $516.87 \mathrm{~cm}^{-1}$, and $435.87 \mathrm{~cm}^{-1}$. A shift of the absorption bands located at 1447.40 and $854.19 \mathrm{~cm}^{-1}$ was observed. Those modifications of the FTIR spectrum may be due to the presence of posnjakite as a new phase in accordance with the results obtained from XRD patterns. Alternatively, the shift of the absorption bands may be evidence of a binding between $\mathrm{Cu}$ and SSP. These results are consistent with previous studies [24, 37, 45].

3.3. XRD Analysis. The crystalline structure of the SSP can be observed by analyzing the results of XRD shown in Figure 2(b). The main diffraction peaks are identified in the range of $2 \theta=25^{\circ}-55^{\circ}$. The most representative peaks with 


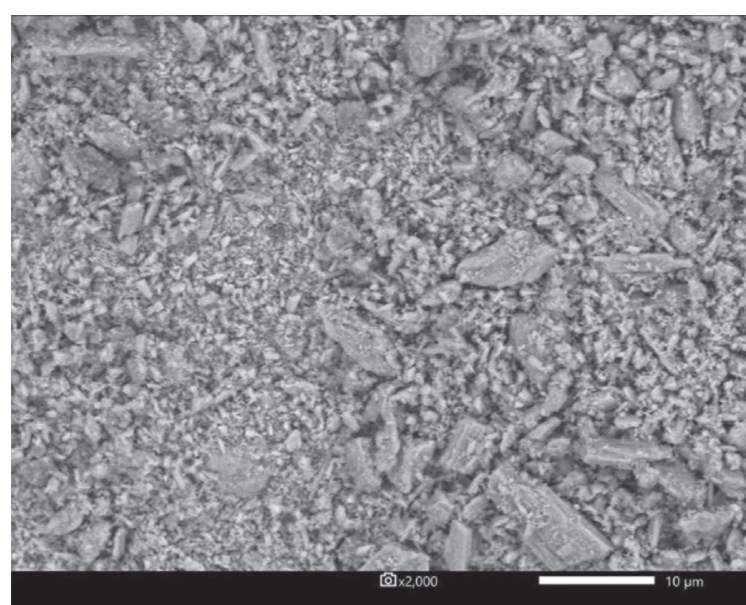

(a)

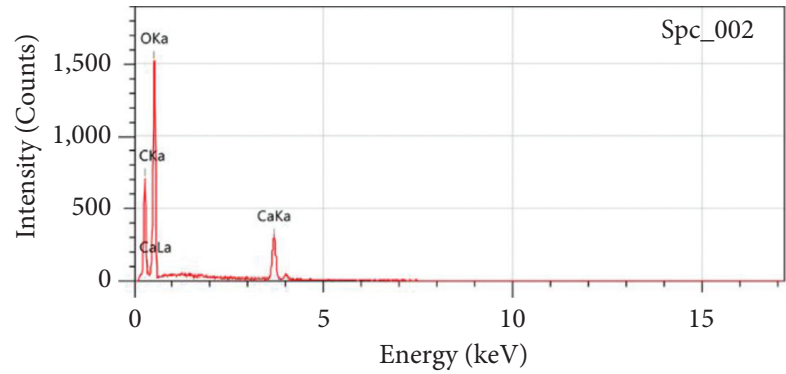

(c)

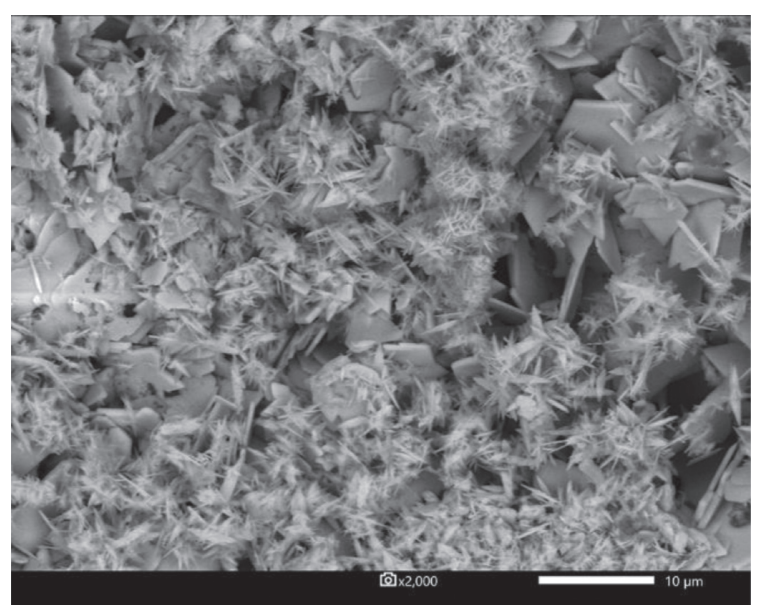

(b)

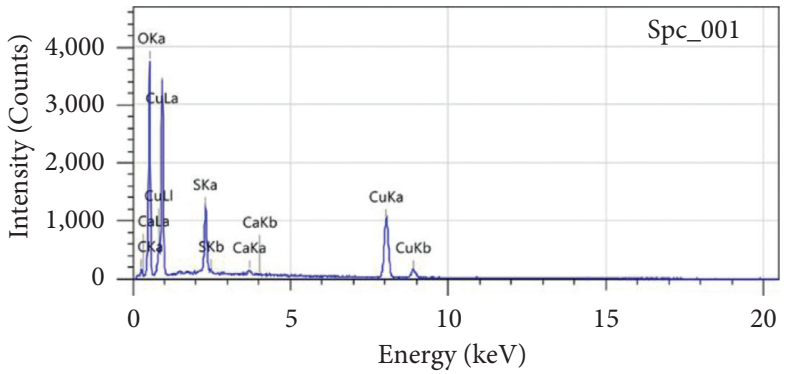

(d)

Figure 1: Images of SSP visualized by SEM: (a) raw SSP; (b) Cu(II) loaded SSP. EDX spectral data: (c) raw SSP; (d) Cu(II) loaded SSP.

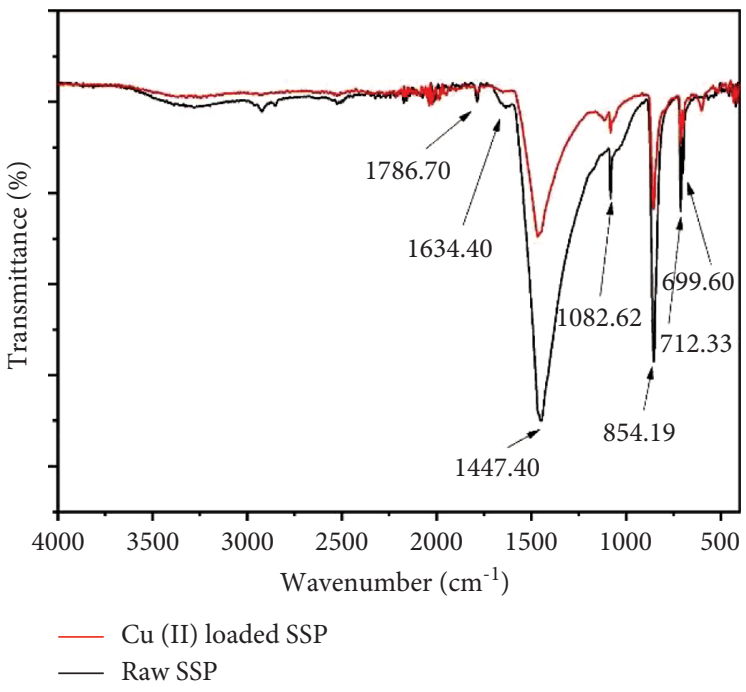

(a)

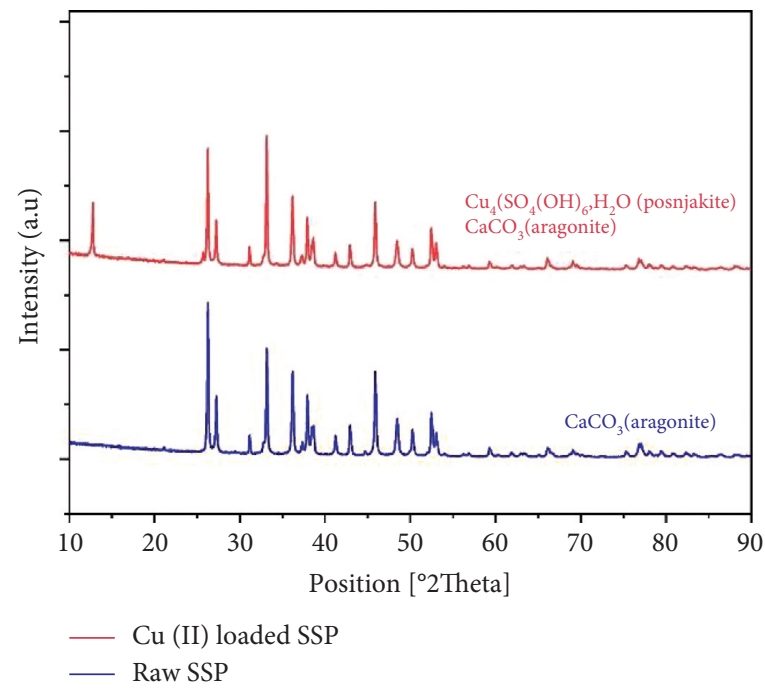

(b)

Figure 2: Characterization of raw SSP and Cu(II) loaded SSP: (a) FTIR spectrum; (b) X-ray patterns.

their miller indices are located at $26.23^{\circ}[111], 27.22^{\circ}[102]$, $33.14^{\circ}$ [201], $36.17^{\circ}$ [020], $37.90^{\circ}$ [211], $45.88^{\circ}$ [122], $48.42^{\circ}$ [220], and $52.47^{\circ}$ [311]. These peaks are assigned to the aragonite crystal form of calcium carbonate $\left(\mathrm{CaCO}_{3}\right)$ as deduced by comparison with the data file COD reference code 96-901-5426. The characterizing of SSP powder was performed with the HighScore Plus software. There are three characteristic crystal phases of $\mathrm{CaCO}_{3}$, namely, aragonite, calcite, and vaterite [43]. $\mathrm{CaCO}_{3}$ that constitutes the snail shells can have two mineralogical forms, calcite and/or aragonite. The calcite crystallizes in the rhomboidal system and aragonite in the orthorhombic system [24]. 
The XRD pattern of $\mathrm{Cu}(\mathrm{II})$ loaded SSP showed the emergence of a new phase assigned to the posnjakite $\left[\mathrm{Cu}_{4}\left(\mathrm{SO}_{4}\right)(\mathrm{OH})_{6}, \mathrm{H}_{2} \mathrm{O}\right]$ as deduced from the comparison with the data file ICDD reference code 00-020-0364. The most representative peaks are located at $12.73^{\circ}, 25.69^{\circ}, 31.12^{\circ}$, $33.13^{\circ}, 34.28^{\circ}, 37.27^{\circ}, 38.60^{\circ}, 44.88^{\circ}, 48.43^{\circ}, 56.83^{\circ}$, and $60.12^{\circ}$. Posnjakite is a monoclinic hydrated copper hydroxyl sulfate belonging to the same group as wroewolfeite and langite [45-47]. $\mathrm{CaCO}_{3}$ dissolved in solution combines with copper ions to produce a precipitate as a new component. The formation of posnjakite is similar to the phenomenon reported by Zhang et al. [38] and Chen et al. [48].

3.4. Kinetic Studies. The effect of contact time was studied to determine the contact time required for SSP to reach the equilibrium with the $\mathrm{Cu}(\mathrm{II})$ (Figure $3(\mathrm{a})$ ). The $\mathrm{Cu}(\mathrm{II})$ adsorption capacity increased with the contact time until it reached a maximum value of $12.2 \mathrm{mg} \cdot \mathrm{g}^{-1}$ at $90 \mathrm{~min}$ and remained constant over time. The removal rate was close to 99\% reducing the concentration of residual copper in the solution to less than $0.5 \mathrm{mg} \cdot \mathrm{L}^{-1}$ to reach a level lower than the permissible limit of $\mathrm{Cu}(\mathrm{II})$ in the drinking water [49].

A contact time of $90 \mathrm{~min}$ was long enough to nearly complete the reaction between $\mathrm{Cu}(\mathrm{II})$ and SPP. This contact time was assumed appropriate for subsequent experiments, in which case the equilibrium could be reached.

The faster $\mathrm{Cu}$ (II) removal rate within the first $30 \mathrm{~min}$ could be attributed to the large number of active sites on the SSP which are accessible for adsorption. Subsequently, the slower elimination rate in the second step may be explained by the steric hindrance induced by the precipitation and diffusion of metals to the surface of the SSP, which reduces the amount of the available sorption sites.

Due to the weak acidity of copper sulfate, the initial $\mathrm{pH}$ of the solution was 4.7. The introduction of SSP increased this $\mathrm{pH}$ to 8.7. The increase in solution $\mathrm{pH}$ was assigned to the consumption of weak acidity from copper sulfate by $\mathrm{CaCO}_{3}$, which is the SSP's main constituent.

The kinetic parameters in equation (4) and (5) could be derived from the slopes and intercepts of the fitted curves shown in Figures 3(c) and 3(d). The rate constants, expected metal uptake, and correlation coefficients are given in Table 1. Regarding the pseudo-first-order model, the correlation coefficient obtained is low, $R^{2}=0.896$, and the predicted metal uptake is much higher than the experimental one. For the pseudo-second-order model, the correlation coefficient obtained was $R^{2}=0.979$ and the predicted metal uptake with this model was $14.075 \mathrm{mg} \cdot \mathrm{g}^{-1}$, which is much nearer to the experimental value of $12.193 \mathrm{mg} \cdot \mathrm{g}^{-1}$. The correlation coefficient obtained for Elovich model was $R^{2}=0.879$. These findings indicate that the adsorption process of $\mathrm{Cu}$ (II) by SSP is based on the pseudo-second-order model. This model has been commonly used to describe chemisorption involving valence forces through the sharing or exchange of electrons as covalent forces and ion exchange between the adsorbent and adsorbent. These results are in accordance with previous findings $[15,19,50]$.

\subsection{Effects of Experimental Parameters}

3.5.1. Effect of $p H$ of the Solution. The amount of removal of the metal ions as a function of $\mathrm{pH}$ is depicted in Figure 4(a). It has been observed that, under highly acidic conditions with a $\mathrm{pH}$ value of 2 , the amount of adsorbed metals was very low, while the adsorption capacity increased with increasing $\mathrm{pH}$ values until a $\mathrm{pH}$ value of 7 was reached. Afterward, the adsorption capacity remained constant in the $\mathrm{pH}$ range between 7 and 10, reaching almost 99\%. These findings corroborate with previous research [21].

The lower removal efficiency at a low $\mathrm{pH}$ is apparently due to an increase of hydrogen ions' concentration in the solution. This may be attributed to the competition between $\mathrm{Cu}(\mathrm{II})$ and hydrogen ions for the same active sites on the SSP surface. Furthermore, as the $\mathrm{pH}$ increases, the hydrogen ion concentration in the solution decreases and the amounts of $\mathrm{HCO}_{3}^{-}$and $\mathrm{CO}_{3}^{2-}$ anions available for reaction increase, leading to enhanced $\mathrm{Cu}(\mathrm{II})$ adsorption by the SSP surface. For $\mathrm{pH}>7$, the copper removal was mainly dominated by precipitation of the hydroxide ions or metal oxides that occur at alkaline $\mathrm{pH}$. These results are consistent with previous research $[21,51]$.

An experiment was carried out in a $50 \mathrm{~mL}$ solution without $\mathrm{Cu}$ (II) having $0.4 \mathrm{~g}$ of SSP at $25^{\circ} \mathrm{C}$ for a contact time of $90 \mathrm{~min}$. The introduction of SSP increased the $\mathrm{pH}$ of the solution from 4.7 to 8.75 . This may be explained by the increase of the amount of $\mathrm{OH}^{-}$by the release of the ionic base such as $\mathrm{CO}_{3}^{2-}$ and $\mathrm{HCO}_{3}^{-}$(equations (9)-(11)).

$$
\begin{array}{r}
\mathrm{CaCO}_{3} \leftrightarrow \mathrm{Ca}^{2+}+\mathrm{CO}_{3}^{2-} \\
\mathrm{CO}_{3}^{2-}+\mathrm{H}_{2} \mathrm{O} \leftrightarrow \mathrm{HCO}_{3}^{-}+\mathrm{OH}^{-} \\
\mathrm{HCO}_{3}^{-}+\mathrm{H}_{2} \mathrm{O} \leftrightarrow \mathrm{H}_{2} \mathrm{CO}_{3}+\mathrm{OH}^{-}
\end{array}
$$

The hydrolysis reaction of SSP leads also to the production of the following chemical species: $\mathrm{Ca}^{2+}, \mathrm{CaOH}^{+}$, and $\mathrm{CaHCO}_{3}{ }^{+}$(equations (12)-(14)) [41, 52, 53]:

$$
\begin{gathered}
\mathrm{HCO}_{3}^{-}+\mathrm{H}^{+} \leftrightarrow \mathrm{H}_{2} \mathrm{O}+\mathrm{CO}_{2} \\
\mathrm{Ca}^{2+}+\mathrm{HCO}_{3}^{-} \leftrightarrow \mathrm{CaHCO}_{3}^{+} \\
\mathrm{Ca}^{2+}+\mathrm{OH}^{-} \leftrightarrow \mathrm{CaOH}^{+}
\end{gathered}
$$

According to the results of our previous works, the pHpzc of SSP was found to be 7.97 [23]. Therefore, at solution $\mathrm{pH}$ lower than 7.97, the surface of SSP is predominated by positive charges and could interact with negative species, while at $\mathrm{pH}$ higher than 7.97, the surface of the SSP is predominated by negative charges and could interact with positive metal species.

According to $\mathrm{pHpzc}$ and considering the hydrolysis reaction of calcite of SSP, it seems that cationic species such as $\mathrm{Ca}^{2+}, \mathrm{CaHCO}_{3}{ }^{+}$, and $\mathrm{CaOH}^{+}$overcome for $\mathrm{pH}<7.97$ and hence offer a positive charge to the SSP surface. At $\mathrm{pH}>7.97$, the negative species such as $\mathrm{CO}_{3}{ }^{2-}$ and $\mathrm{HCO}_{3}{ }^{-}$prevail. The effect of $\mathrm{pH}$ can be explained by the ion-exchange 


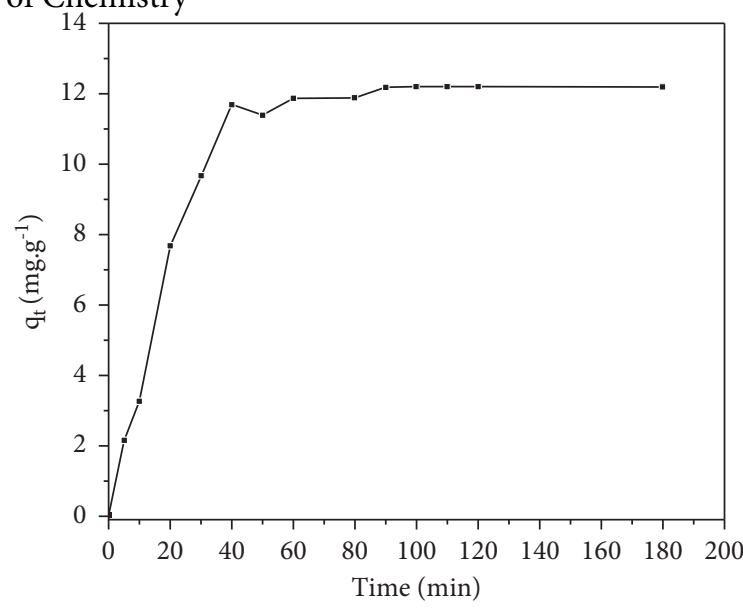

(a)

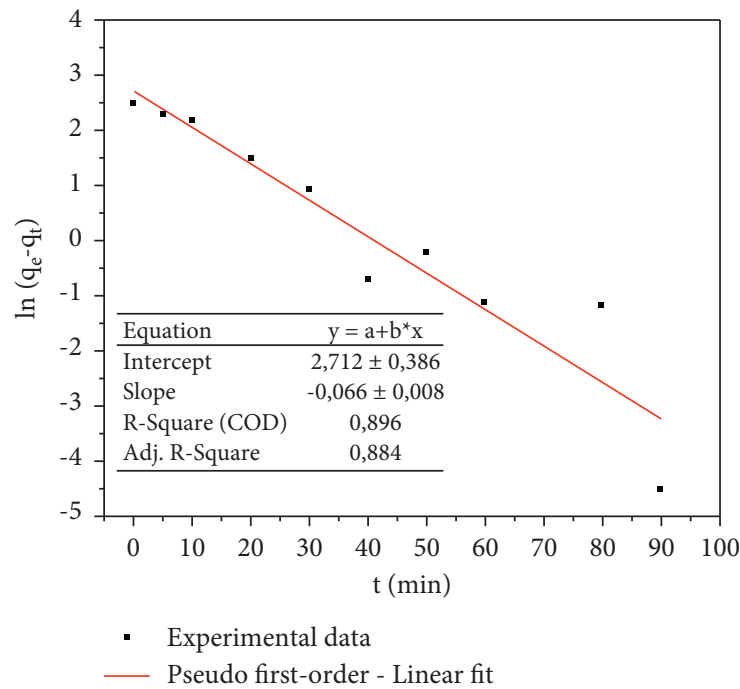

(c)

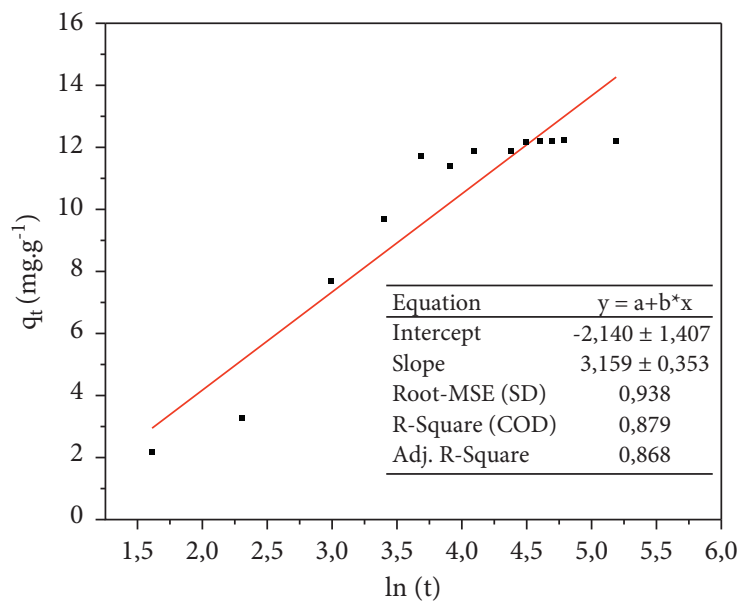

- Experimental data

_ Elovich model-linear fit

(b)

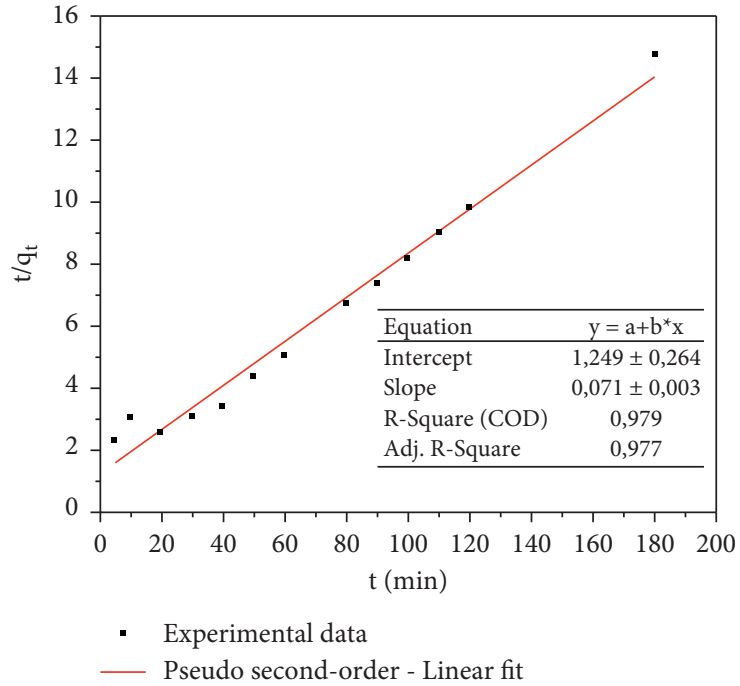

(d)

Figure 3: Kinetics of Cu(II) removal by SSP: (a) effect of time; (b) Elovich model; (c) pseudo-first-order model; (d) pseudo-second-order model (pH: 4.7; $\mathrm{Cu}(\mathrm{II})$ concentration: $100 \mathrm{mg} \cdot \mathrm{L}^{-1}$; dose: $8 \mathrm{~g} \cdot \mathrm{L}^{-1}$; agitation speed: $200 \mathrm{rpm}$; particle size: $300 \mu \mathrm{m}$; temperature: $25^{\circ} \mathrm{C}$ ).

TABLE 1: Parameters and correlation coefficients obtained from the analysis of adsorption kinetics by pseudo-first-order model, pseudosecond-order model, and Elovich equation.

\begin{tabular}{|c|c|c|c|c|c|}
\hline \multirow{3}{*}{$\frac{\text { Kinetic model }}{\text { Pseudo-first-order }}$} & \multicolumn{5}{|c|}{ Parameter } \\
\hline & $k_{1}\left(\min ^{-1}\right)$ & $q_{\mathrm{e}, \mathrm{cal}}\left(\mathrm{mg} \cdot \mathrm{g}^{-1}\right)$ & $q_{e, \exp }\left(m g \cdot g^{-1}\right)$ & $R^{2}$ & $R_{\text {adj }}^{2}$ \\
\hline & 0.066 & 15.064 & 12.193 & 0.896 & 0.884 \\
\hline Pseudo-second-order & $k_{2}\left(\mathrm{~g} \cdot \mathrm{mg}^{-1} \cdot \min ^{-1}\right)$ & $q_{\mathrm{e}, \mathrm{cal}}\left(\mathrm{mg} \cdot \mathrm{g}^{-1}\right)$ & $q_{\mathrm{e}, \exp }\left(\mathrm{mg} \cdot \mathrm{g}^{-1}\right)$ & $R^{2}$ & $R_{\text {adj }}^{2}$ \\
\hline Flovich & \multirow{2}{*}{\multicolumn{2}{|c|}{$\beta\left(\mathrm{mg} \cdot \mathrm{g}^{-1}\right)$}} & $\alpha\left(\mathrm{mg} \cdot \mathrm{g}^{-1} \cdot \mathrm{min}^{-1}\right)$ & $\begin{array}{c}0.979 \\
R^{2}\end{array}$ & $R_{\text {adj }}^{2}$ \\
\hline & & & 1.605 & 0.879 & 0.868 \\
\hline
\end{tabular}

adsorption mechanism that occurs on the SSP surface, in which carbonate groups play an important role. The increase of calcium concentrations in the solution after $\mathrm{Cu}$ (II) adsorption resulted from the dissolution of $\mathrm{CaCO}_{3}$.

The substitution process of $\mathrm{Cu}^{2+}$ with $\mathrm{Ca}^{2+}$ defined as ion exchange may be responsible for copper uptake in the solution. The same result has been reported in other studies using different heavy metals $[41,42,54,55]$. The binding due to cation exchange between $\mathrm{Cu}^{2+}$ and $\mathrm{Ca}^{2+}$ can be presented as follows:

$$
\begin{gathered}
\mathrm{CaCO}_{3}+\mathrm{Cu}^{2+} \longrightarrow \mathrm{CuCO}_{3}+\mathrm{Ca}^{2+} \\
\mathrm{CaCO}_{3}+\mathrm{Cu}^{2+}+\mathrm{CO}_{3}^{2-} \longrightarrow(\mathrm{Ca}, \mathrm{Cu}) \mathrm{CO}_{3}
\end{gathered}
$$




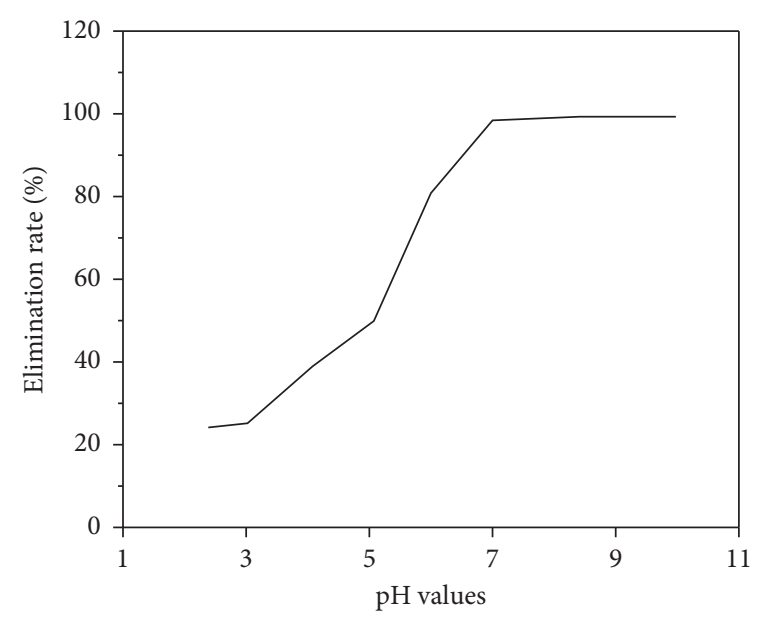

(a)

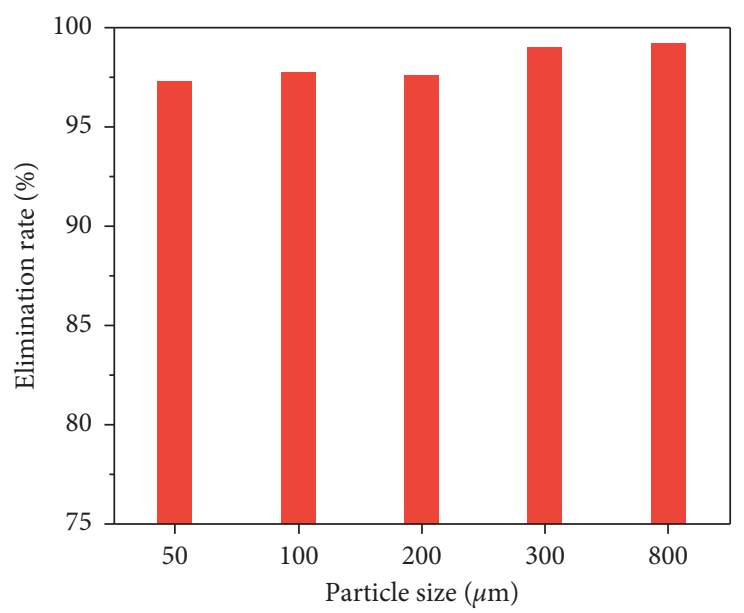

(c)

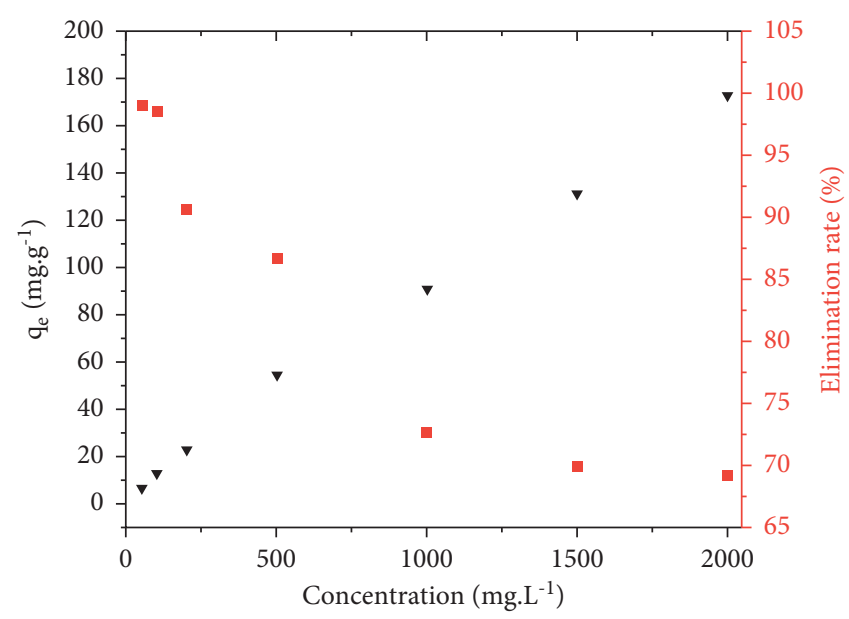

(b)

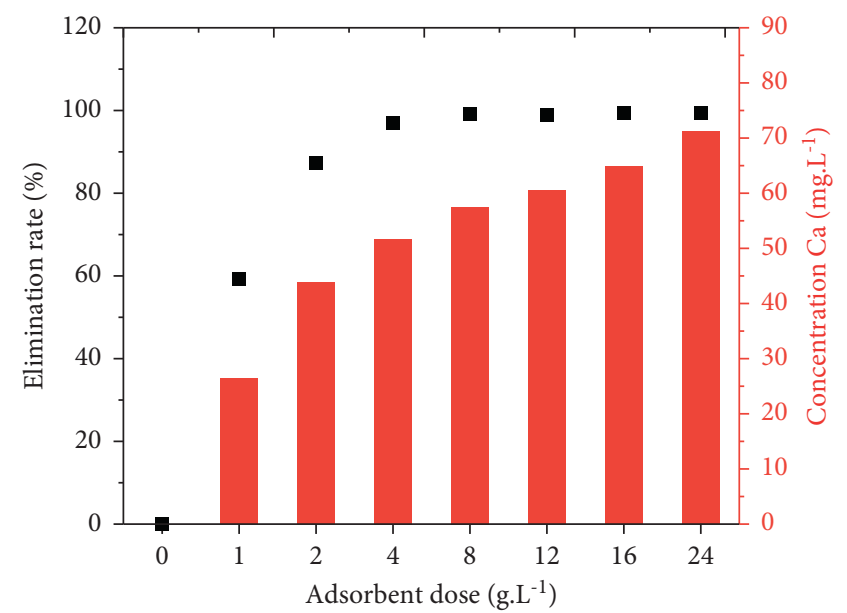

(d)

FIGURE 4: Effect of different experimental parameters on $\mathrm{Cu}$ (II) adsorption by SSP: (a) pH; (b) initial Cu(II) concentration; (c) particle size; (d) adsorbent dose.

3.5.2. Effect of Particle Size. The particle size distribution of SSP obtained through the particle size analysis is presented in Table 2. Approximately $44.5 \%$ of SSP particles presented size of $300 \mu \mathrm{m}$, which represents the largest proportion of the sample $(89 \mathrm{~g})$. The particle size distribution curve obtained through the sieve analysis is available in our previous studies [23].

Moreover, the effect of particle size on the percent of $\mathrm{Cu}$ (II) removal is presented in Figure 4(c). Experimental results showed that the effect of particle size on the removal percentage was insignificant. Nonetheless, the particle size of more than $300 \mu \mathrm{m}$ was found to yield the highest removal percentage of $\mathrm{Cu}$ (II). Therefore, a particle size of $300 \mu \mathrm{m}$ was selected for this experimental study to decrease the future cost of material preparation.

3.5.3. Effect of SSP Dose. The $\mathrm{Cu}(\mathrm{II})$ removal efficiency was significantly influenced by the amount of SSP as evident from Figure 4(d). The removal efficiency of $\mathrm{Cu}(\mathrm{II})$ was increased with increasing SSP concentration. The maximum removal of $\mathrm{Cu}(\mathrm{II})$ from the aqueous solutions occurred with
TABle 2: Particle size distribution of SSP.

\begin{tabular}{lcc}
\hline Size $(\mu \mathrm{m})$ & Mass $(\mathrm{g})$ & Percentage mass $(\%)$ \\
\hline$>800$ & 42 & 21 \\
300 & 89 & 44.5 \\
200 & 17 & 8.5 \\
100 & 20 & 10 \\
$<50$ & 31 & 15.5 \\
\hline
\end{tabular}

$8 \mathrm{~g} \cdot \mathrm{L}^{-1}$ of SSP and remained almost unchanged thereafter. This observation was mainly due to the saturation of the active sites in SSP and the establishment of the adsorption equilibrium. Indeed, the increase in the mass of SSP could provide enough adsorption sites for the metal ions and also increase the contact between the $\mathrm{Cu}(\mathrm{II})$ and the adsorbent. Several researchers have reported similar results $[24,56]$.

3.5.4. Effect of Initial Concentrations on Cu(II) Removal. Figure 4(b) shows the effect of initial concentration on $\mathrm{Cu}$ (II) uptake by SSP. The material shows a high elimination 
rate close to $99 \%$ with an initial $\mathrm{Cu}$ (II) concentration of $100 \mathrm{mg} \cdot \mathrm{L}^{-1}$. This percentage decreases as the $\mathrm{Cu}(\mathrm{II})$ concentration further increases. Meanwhile, at a used concentration of $2000 \mathrm{mg} \cdot \mathrm{L}^{-1}$, the elimination rate was found to be nearly $69 \%$. The removal efficiency declined clearly at higher concentrations. However, a good $\mathrm{Cu}$ (II) removal efficiency was observed when the metal ions concentrations were less than $500 \mathrm{mg} \cdot \mathrm{L}^{-1}$. As the percentage adsorbed decreased with increasing initial concentration, the equilibrium adsorption capacity increased, indicating increasing occupation of available binding sites. These findings are in agreement with previous studies [21].

3.6. Equilibrium Isotherms. Both the Langmuir and Freundlich models were used to describe adsorption isotherms. The nonlinear expression of the Langmuir isotherm model is given as

$$
q_{e}=\frac{q_{\max } K_{L} C_{e}}{1+K_{L} C_{e}},
$$

where $C_{\mathrm{e}}$ is the equilibrium $\mathrm{Cu}(\mathrm{II})$ concentration $\left(\mathrm{mg} \cdot \mathrm{L}^{-1}\right)$, $q_{\mathrm{e}}$ is the amount of $\mathrm{Cu}(\mathrm{II})$ adsorbed at equilibrium $\left(\mathrm{mg} \cdot \mathrm{g}^{-1}\right)$, $q_{\text {max }}$ is the maximum saturated monolayer adsorption capacity $\left(\mathrm{mg} \cdot \mathrm{g}^{-1}\right)$, and $K_{\mathrm{L}}$ is the Langmuir constant $\left(\mathrm{L} \cdot \mathrm{mg}^{-1}\right)$ related to the energy of adsorption which quantitatively reflects the affinity of binding sites. The Langmuir model can be expressed in terms of a constant known as separation factor or equilibrium parameter $\left(R_{\mathrm{L}}\right)$ given by the following equation [57]:

$$
R_{L}=\frac{1}{1+K_{L} C_{0}}
$$

where $K_{\mathrm{L}}$ is the Langmuir equilibrium constant $\left(\mathrm{L} \cdot \mathrm{mg}^{-1}\right)$ and $\mathrm{C}_{0}$ is the initial $\mathrm{Cu}(\mathrm{II})$ concentration $\left(\mathrm{mg} \cdot \mathrm{L}^{-1}\right)$. It has been recognized that, for favorable isotherm shapes, $R_{\mathrm{L}}$ must be between 0 and 1 [58].

The nonlinear expression of the Freundlich isotherm model is given as [30]

$$
q_{e}=K_{F} C_{e}^{1 / n}
$$

where $K_{\mathrm{F}}\left(\mathrm{mg} \cdot \mathrm{g}^{-1}\right)\left(\mathrm{L} \cdot \mathrm{mg}^{-1}\right)^{1 / n}$ and $n$ (dimensionless) are Freundlich isotherm constants, $C_{\mathrm{e}}\left(\mathrm{mg} \cdot \mathrm{L}^{-1}\right)$ is the $\mathrm{Cu}(\mathrm{II})$ concentration at equilibrium, and $q_{\mathrm{e}}\left(\mathrm{mg} \cdot \mathrm{g}^{-1}\right)$ is the amount of $\mathrm{Cu}(\mathrm{II})$ adsorbed at equilibrium.

The representations of Langmuir and Freundlich isotherms of $\mathrm{Cu}(\mathrm{II})$ adsorption at $25^{\circ} \mathrm{C}$ are given in Figure $5(\mathrm{a})$. Their parameters are listed in Table 3. The values of $R^{2}$ and $R_{\text {adj }}^{2}$ were high for both models. The Langmuir isotherm assumes a completely homogeneous surface, while the Freundlich isotherm is suitable for highly heterogeneous surfaces. The $R_{\mathrm{L}}$ results were found to be between 0 and 1 . Therefore, the adsorption of the $\mathrm{Cu}$ (II) by SSP was favorable. The calculated $q_{\max }$ was found to be $905.08 \mathrm{mg} \cdot \mathrm{g}^{-1}$, which is greater than that found for Anadara inaequivalvis mollusk shells, $q_{\max }=384.6 \mathrm{mg} \mathrm{g}^{-1}[24]$.
3.7. Thermodynamic Study. The values of $\Delta H^{\circ}$ and $\Delta S^{\circ}$ can be obtained through the Van't Hoff plots in Figure 5(b). The thermodynamic parameters for adsorption of $\mathrm{Cu}$ (II) by SSP are listed in Table 4 . The negative values of $\Delta G^{\circ}$ indicated that the adsorption phenomenon occurred favorably and spontaneously. The negative values of $\Delta H^{\circ}$ suggested the exothermic nature of the process. Thus, the total energy absorbed in bonds breaking is lower than the total energy released in bonds making, causing the release of extra energy in the form of heat during the adsorptive process $[33,59]$. The positive values of $\Delta \mathrm{S}^{\circ}$ suggested a rise in the randomness and disorder at the solid/solution interface during the adsorption of $\mathrm{Cu}(\mathrm{II})$.

3.8. Mechanism of Copper Removal by SSP. While hydroxide complexes are always present in water, individual anions or combinations of them can bind to $\mathrm{Cu}$ (II) to form complexes. $\mathrm{Cu}$ (II) will form complexes with common anions, including $\mathrm{OH}^{-}, \mathrm{HCO}_{3}{ }^{-}, \mathrm{CO}_{3}{ }^{2-}$, and $\mathrm{SO}_{4}{ }^{2-}$. The common precipitates are malachite $\left[\mathrm{Cu}_{2}\left(\mathrm{CO}_{3}\right)(\mathrm{OH})_{2}\right][60,61]$, langite $\left[\mathrm{Cu}_{4}\left(\mathrm{SO}_{4}\right)\right.$ $\left.(\mathrm{OH})_{6}, 2 \mathrm{H}_{2} \mathrm{O}\right]$ [47], and posnjakite $\left[\mathrm{Cu}_{4}\left(\mathrm{SO}_{4}\right)(\mathrm{OH})_{6}, \mathrm{H}_{2} \mathrm{O}\right]$ $[38,45]$.

Both XRD and microstructure results demonstrate the manifestation of a new phase of copper sulfate, probably posnjakite $\left[\mathrm{Cu}_{4}\left(\mathrm{SO}_{4}\right)(\mathrm{OH})_{6}, \mathrm{H}_{2} \mathrm{O}\right]$. The possible precipitation reaction produced by the SSP may be represented by the following formula [38]:

$$
\begin{gathered}
4 \mathrm{Cu}^{2+}+4 \mathrm{SO}_{4}^{2-}+4 \mathrm{CaCO}_{3}+5 \mathrm{H}_{2} \mathrm{O} \longrightarrow \mathrm{Cu}_{4}\left(\mathrm{SO}_{4}\right)(\mathrm{OH})_{6} \\
\cdot \mathrm{H}_{2} \mathrm{O} \downarrow+3 \mathrm{SO}_{4}^{2-}+4 \mathrm{Ca}^{2+}+2 \mathrm{HCO}_{3}^{-}+2 \mathrm{CO}_{2} \uparrow
\end{gathered}
$$

The removal of $\mathrm{Cu}(\mathrm{II})$ can be predicted as a mixture of two effects. Firstly, the rough surface of SSP gives solid contact, resulting in chemisorption of metal ions through ion-exchange mechanism at low concentrations ((15) and (16). Secondly, the presence of dissolved $\mathrm{CaCO}_{3}$ leads to the increase of $\mathrm{pH}$, which causes metal precipitation (see formula (20)). Figure 6 gives a schematic description of the mechanism of $\mathrm{Cu}$ (II) fixation by SSP. Adsorption and precipitation involve characteristic reactions of $\mathrm{Cu}$ (II) with $\mathrm{CaCO}_{3}$ surfaces, with precipitation dominating at high concentrations of metal. Moreover, the final $\mathrm{pH}$ after $\mathrm{Cu}$ (II) removal stayed in the neutral range, allowing direct discharge of the water without further adjustment. Indeed, typically tolerable discharges into surface watercourses are limited to a $\mathrm{pH}$ range of 6 to 9 . Water discharge outside these limits is harmful to the environment $[62,63]$.

3.9. Use of the Residual SSP for the Production of Valuable Compounds. Calcination is a thermal decomposition process that requires substantial energy consumption. Nevertheless, it showed the extreme importance to deal with complex waste. Indeed, it allows in a one-step process 


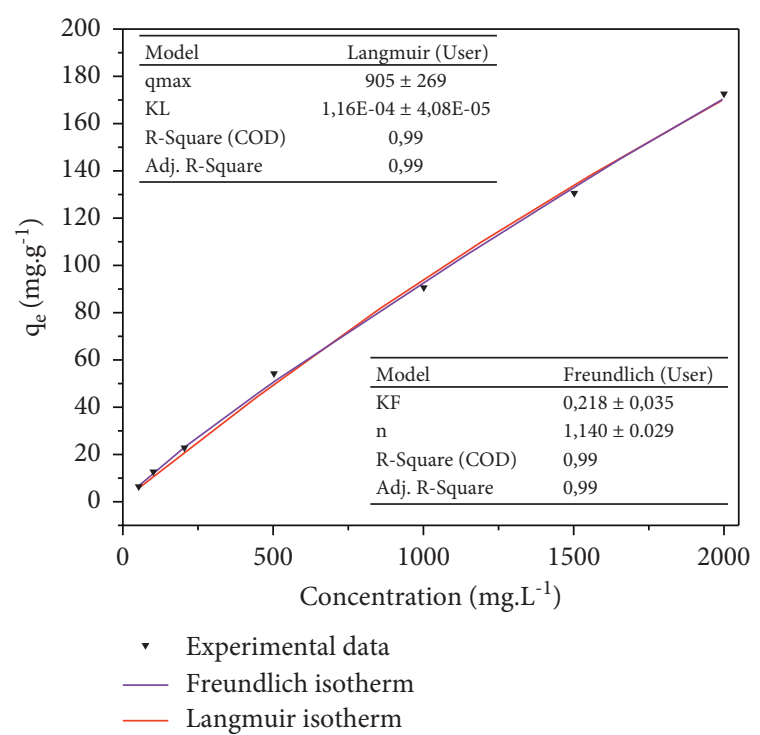

(a)

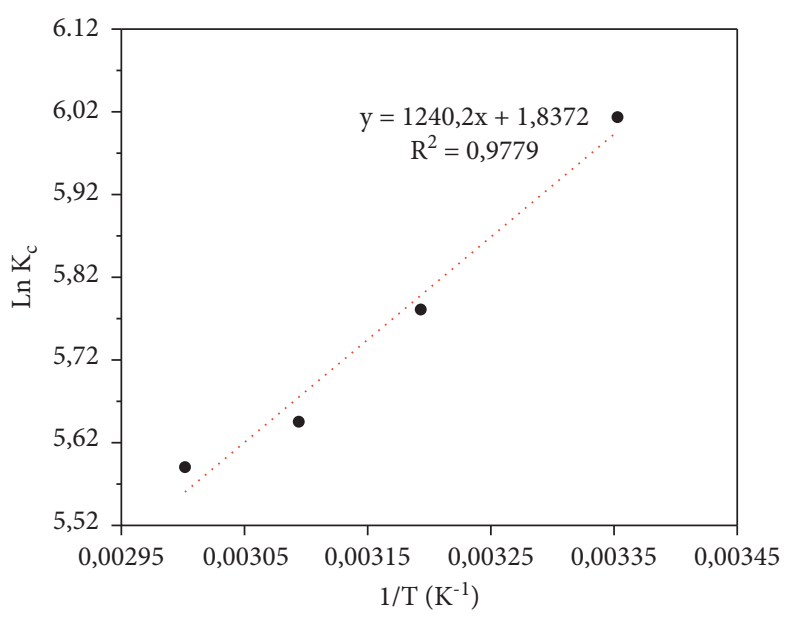

(b)

Figure 5: $\mathrm{Cu}(\mathrm{II})$ adsorption by SSP: (a) isotherm fitting of Langmuir and Freundlich; (b) plot of $\ln K_{\mathrm{c}}$ versus $1 / \mathrm{T}$.

TABLE 3: Isotherms parameters of $\mathrm{Cu}(\mathrm{II})$ adsorption by SSP.

\begin{tabular}{lcccc}
\hline Model & Parameter & Value & & \\
\hline \multirow{4}{*}{ Langmuir } & $q_{\max }\left({\mathrm{mg} \cdot \mathrm{g}^{-1}}^{-1}\right.$ & 905.08 & & \\
& $K_{\mathrm{L}}\left(\mathrm{L} \cdot \mathrm{mg}^{-1}\right)$ & $1.16 E-04$ & $R_{\text {adj }}^{2}$ & 0.99 \\
\multirow{2}{*}{ Freundlich } & $R_{\mathrm{L}}$ & $0.994-0.812$ & $R^{2}$ & 0.99 \\
& $K_{\mathrm{F}}\left(\mathrm{mg} \cdot \mathrm{g}^{-1}\right)\left(\mathrm{L} \cdot \mathrm{mg}^{-1}\right)^{1 / n}$ & 0.22 & $R_{\text {adj }}^{2}$ & 0.99 \\
& $n$ & 1.14 & $R^{2}$ & 0.99 \\
\hline
\end{tabular}

TABLE 4: Thermodynamic parameters for the adsorption of $\mathrm{Cu}(\mathrm{II})$ by SSP.

\begin{tabular}{cccc}
\hline$T(\mathrm{~K})$ & $\Delta G^{0}\left(\mathrm{~kJ} \cdot \mathrm{mol}^{-1}\right)$ & $\Delta H^{0}\left(\mathrm{~kJ} \cdot \mathrm{mol}^{-1}\right)$ & $\Delta S^{0}\left(\mathrm{~J} \cdot \mathrm{mol}^{-1} \cdot \mathrm{K}^{-1}\right)$ \\
\hline 298.15 & -14.91 & & \\
313.15 & -15.05 & -10.31 & 15.28 \\
323.15 & -15.17 & & \\
333.15 & -15.48 & & \\
\hline
\end{tabular}

the formation of a reusable component or a waste generally more stable than the original one.

The residual product after the $\mathrm{Cu}(\mathrm{II})$ removal by SSP is mainly composed of $\mathrm{CaCO}_{3}$ and posnjakite. It can be used as a precursor to synthesize mixed oxide, which is composed of copper (II) oxide $(\mathrm{CuO})$, calcium oxide $(\mathrm{CaO})$, and calcium copper oxide $\left(\mathrm{Ca}_{2} \mathrm{CuO}_{3}\right)$. Figure 7 (a) illustrates the preparation process of the mixed solid oxides. As shown in Figure 7(c), $\mathrm{CaCO}_{3}$ was obtained as the main phase in the calcined residual SSP at a temperature of $700^{\circ} \mathrm{C}$, while $\mathrm{CuO}$ and $\mathrm{CaO}$ were obtained as a minor phase.

The reaction pathway of the thermal decomposition of posnjakite to $\mathrm{CuO}$ included the thermal dehydration and desulfurization processes. It can be expressed by the following reaction [64]:

$$
\mathrm{Cu}_{4}\left(\mathrm{SO}_{4}\right)(\mathrm{OH})_{6} \cdot \mathrm{H}_{2} \mathrm{O} \stackrel{700^{\circ} \mathrm{C}}{\longrightarrow} 4 \mathrm{CuO}+4 \mathrm{H}_{2} \mathrm{O}+\mathrm{SO}_{2}+\frac{1}{2} \mathrm{O}_{2}
$$

By increasing temperature to $900^{\circ} \mathrm{C}$, the diffraction peaks corresponding to $\mathrm{Ca}_{2} \mathrm{CuO}_{3}$ appear as reported elsewhere [65]. Residual SSP calcined at $900^{\circ} \mathrm{C}$ was a mixed solid oxide consisting of $\mathrm{CaO}$ as the main phase and $\mathrm{Ca}_{2} \mathrm{CuO}_{3}$ as the minor phase.

The TGA measurements of SSP reveal that the major weight loss (40.18\%) occurs in the temperature range of 668 to $870^{\circ} \mathrm{C}$ (Figure $7(\mathrm{~b})$ ). It may be attributed to the endothermic decomposition of $\mathrm{CaCO}_{3}$ to calcium oxide $(\mathrm{CaO})$ and carbon dioxide $\left(\mathrm{CO}_{2}\right)$. It can be expressed by the following reaction:

$$
\mathrm{CaCO}_{3}(\mathrm{~s}) \leftrightarrow \mathrm{CaO}(\mathrm{s})+\mathrm{CO}_{2}(\mathrm{~g})
$$

The proposed method is chemical-free and efficient in terms of time. Moreover, it allows the valorization of the residual SSP. The mixed oxide obtained can be applied in different areas. Indeed, $\mathrm{CuO}$ nanoparticle is employed in a broad variety of practical applications such as catalysis for biodiesel production, gas sensors, thermoelectric materials, batteries, and ceramic pigments [66-68]. Furthermore, copper nanoparticles exhibit extraordinary performance as antibacterial and antimicrobial agents [69, 70]. $\mathrm{CaO}$ is extensively used in water and sewage treatment, in Portland cement production, in soil stabilization, and in biomedicine [71-73]. Mixed metal oxides have been widely used for various applications such as pigments in coatings and catalysts for transesterification of triglyceride $[74,75]$.

The increasing costs and the environmental considerations associated with the use of commercial adsorbents have led to the development of alternative low-cost adsorbents derived from renewable resources. The use of natural 


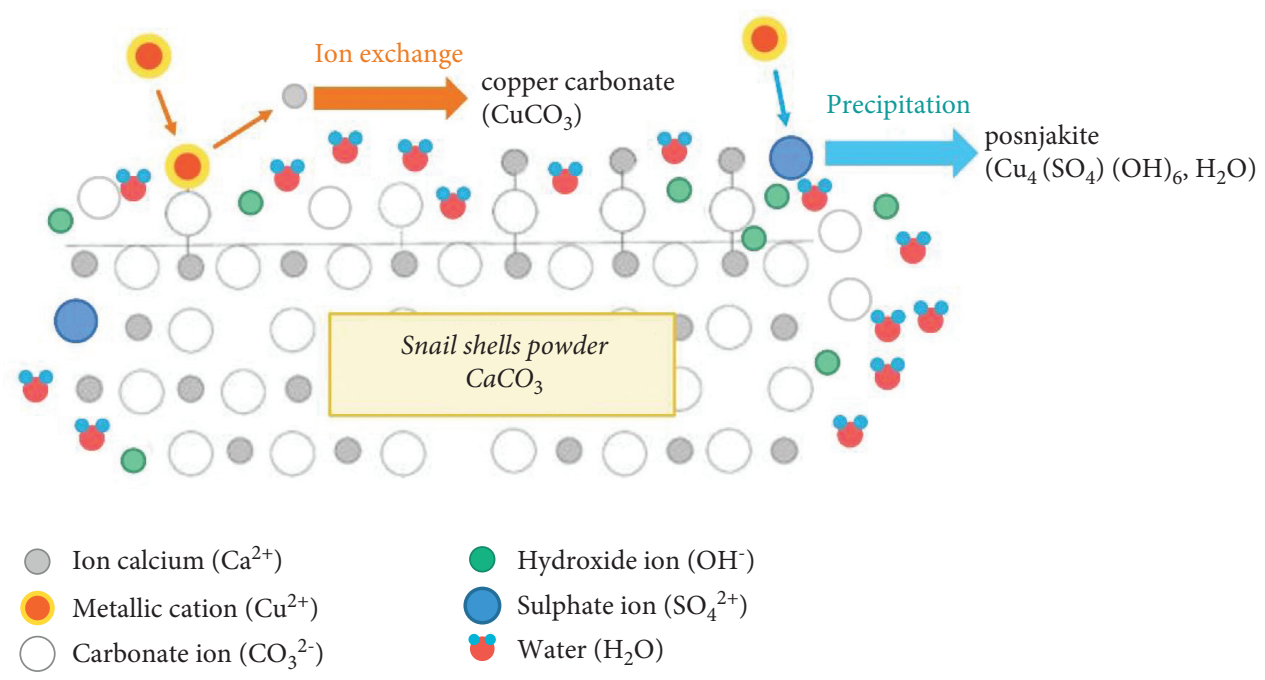

FIGURE 6: Schematic diagram of $\mathrm{Cu}(\mathrm{II})$ fixation by chemical precipitation and ion-exchange mechanism.
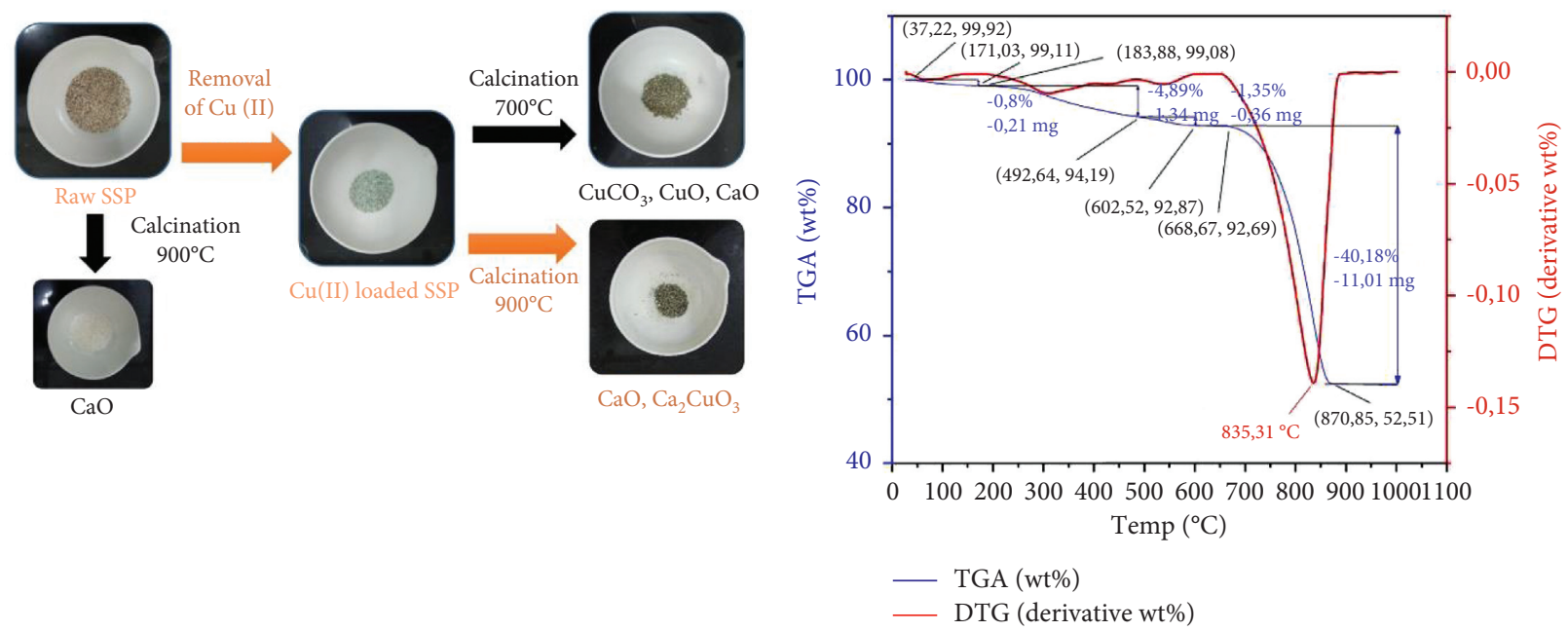

(a)

(b)

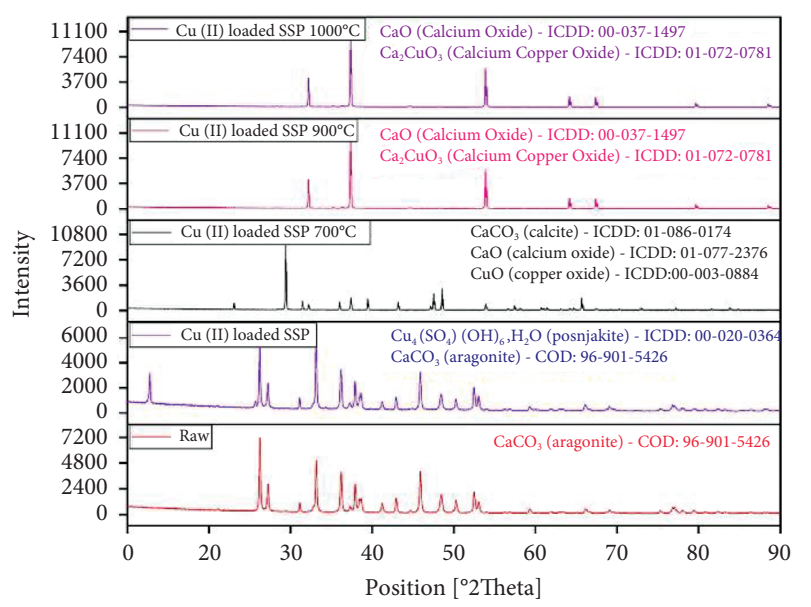

(c)

FigURE 7: (a) Calcination of Cu(II) loaded SSP. (b) Thermogravimetric Analysis (TGA) and derivative thermogravimetry (DTG) profiles of SSP. (c) XRD patterns comparison for raw SSP, $\mathrm{Cu}(\mathrm{II})$ loaded SSP, and $\mathrm{Cu}(\mathrm{II})$ loaded SSP calcined at 700,900 , and $1000^{\circ} \mathrm{C}$ along with their data file reference (COD: Crystallography Open Database, ICDD: International Centre for Diffraction Data). 
TABle 5: Comparison of $\mathrm{Cu}(\mathrm{II})$ adsorption studies using various adsorbents.

\begin{tabular}{lcc}
\hline Adsorbent & Adsorption capacity $\left(\mathrm{mg}^{-1} \mathrm{~g}^{-1}\right)$ & Reference \\
\hline SSP & 905.08 & This study \\
Mollusk shells & 384.6 & {$[24]$} \\
Raw corn silk & 15.35 & {$[76]$} \\
Bentonite & 56.95 & {$[77]$} \\
Apricot stones & 5.90 & {$[78]$} \\
Maple sawdust & 9.19 & {$[79]$} \\
Pine cones powder & 9.08 & {$[80]$} \\
\hline
\end{tabular}

materials for heavy metals removal is a new, economic, efficient, and eco-friendly alternative over conventional treatment methods. The SSP used in this research is an available and inexpensive material that can be used to support both the goals of water purification and resource recovery. Table 5 presents the comparison of adsorption capacities of various adsorbents for $\mathrm{Cu}(\mathrm{II})$.

\section{Conclusion}

The present research investigated the efficiency of SSP for $\mathrm{Cu}$ (II) removal from contaminated aqueous solutions and the production of valuable compounds from the residual product. The removal of $\mathrm{Cu}(\mathrm{II})$ was reasonably fast to be completed within a time frame of $90 \mathrm{~min}$. The kinetics of adsorption following the pseudo-second-order model $\left(R^{2}=0.979\right)$ were better compared to the pseudo-first-order model $\left(R^{2}=0.896\right)$. The amount of $\mathrm{Cu}$ (II) adsorbed increases with increasing $\mathrm{pH}$ value until a $\mathrm{pH}$ of 7 was reached. The maximum $\mathrm{Cu}$ (II) removal occurred with a mass of SSP equal to $8 \mathrm{~g} \cdot \mathrm{L}^{-1}$ and a particle size of $300 \mu \mathrm{m}$. This particle size presents approximately $44.5 \%$ of SSP particles, which is the largest proportion of the sample as shown by particle size analysis. The adsorption process obeyed the Freundlich and the Langmuir adsorption isotherms. The thermodynamic analysis indicated that the $\mathrm{Cu}(\mathrm{II})$ adsorption by SSP was a spontaneous and exothermic process. The adsorption mechanism on the SSP surface is considered to be ion exchange and precipitation as posnjakite. SSP exhibits an excellent ability to remove $\mathrm{Cu}(\mathrm{II})$. The $\mathrm{Cu}$ (II) removal rate could reach almost $99 \%$ for a concentration of $100 \mathrm{mg} \cdot \mathrm{L}^{-1}$. After $\mathrm{Cu}(\mathrm{II})$ removal, the final $\mathrm{pH}$ was in the neutral range, which allowed direct water discharge without further adjustment. Calcite form of $\mathrm{CaCO}_{3}$ was obtained as the main phase in the residual SSP at a temperature of $700^{\circ} \mathrm{C}$, while $\mathrm{CuO}$ and $\mathrm{CaO}$ were obtained as a minor phase. $\mathrm{CaO}$ as the main phase and $\mathrm{Ca}_{2} \mathrm{CuO}_{3}$ as the minor phase were obtained in the residual SSP calcined at $900^{\circ} \mathrm{C}$. The proposed method is efficient in terms of time and does not require chemical compounds or expensive raw materials. It is expected that this simple approach can be used as an inexpensive and convenient method for the removal of $\mathrm{Cu}$ (II) from aqueous solutions and the production of mixed oxide.

\section{Data Availability}

No data were used to support this study.

\section{Conflicts of Interest}

The authors declare that there are no conflicts of interest regarding the publication of this article.

\section{References}

[1] M. A. A. Wijayawardena, M. Megharaj, and R. Naidu, "Exposure, toxicity, health impacts, and bioavailability of heavy metal mixtures," in Advances in Agronomy, pp. 175-234, Elsevier Inc., Amsterdam, Netherlands, 2016.

[2] World Health Organization, Trace Elements in Human Nutrition and Health, World Health Organization, Geneva, Switzerland, 1996.

[3] V. Krstić, T. Urošević, and B. Pešovski, "A review on adsorbents for treatment of water and wastewaters containing copper ions," Chemical Engineering Science, vol. 192, pp. 273-287, 2018.

[4] Z. Al-Qodah, M. A. Yahya, and M. Al-Shannag, "On the performance of bioadsorption processes for heavy metal ions removal by low-cost agricultural and natural by-products bioadsorbent: a review," Desalination and Water Treatment, vol. 85, pp. 339-357, 2017.

[5] M. K. Uddin, "A review on the adsorption of heavy metals by clay minerals, with special focus on the past decade," Chemical Engineering Journal, vol. 308, pp. 438-462, 2017.

[6] M. A. Barakat, "New trends in removing heavy metals from industrial wastewater," Arabian Journal of Chemistry, vol. 4, no. 4, pp. 361-377, 2011.

[7] J. Wang and C. Chen, "Biosorbents for heavy metals removal and their future," Biotechnology Advances, 2009.

[8] I. Michalak, K. Chojnacka, and A. Witek-Krowiak, "State of the art for the biosorption process-a review," Applied Biochemistry and Biotechnology, vol. 170, no. 6, pp. 1389-1416, 2013.

[9] S. Babel and T. A. Kurniawan, "Low-cost adsorbents for heavy metals uptake from contaminated water: a review," Journal of Hazardous Materials, vol. 97, no. 1-3, pp. 219-243, 2003.

[10] S. Kushwaha, H. Soni, V. Ageetha, and P. Padmaja, "An insight into the production, characterization, and mechanisms of action of low-cost adsorbents for removal of organics from aqueous solution," Critical Reviews in Environmental Science and Technology, vol. 43, no. 5, pp. 443-549, 2013.

[11] C. Palma, E. Contreras, J. Urra, and M. J. Martínez, "Ecofriendly technologies based on banana peel use for the decolourization of the dyeing process wastewater," Waste and Biomass Valorization, vol. 2, no. 1, pp. 77-86, 2011.

[12] Y. C. Sharma, V. Srivastava, V. K. Singh, S. N. Kaul, and C. H. Weng, "Nano-adsorbents for the removal of metallic pollutants from water and wastewater," Environmental Technology, vol. 30, no. 6, pp. 583-609, 2009.

[13] D. Sud, G. Mahajan, and M. Kaur, "Agricultural waste material as potential adsorbent for sequestering heavy metal ions from aqueous solutions - a review," Bioresource Technology, vol. 99, no. 14, pp. 6017-6027, 2008.

[14] F. Alakhras, "Biosorption of Cd(II) ions from aqueous solution using chitosan-iso-vanillin as a low-cost sorbent: equilibrium, kinetics, and thermodynamic studies," Arabian Journal for Science and Engineering, vol. 44, no. 1, pp. 279288, 2019.

[15] A. Labidi, A. M. Salaberria, S. C. M. Fernandes, J. Labidi, and M. Abderrabba, "Adsorption of copper on chitin-based materials: kinetic and thermodynamic studies," Journal of the 
Taiwan Institute of Chemical Engineers, vol. 65, pp. 140-148, 2016.

[16] F. Alakhras, E. Al-Abbad, N. O. Alzamel, F. M. Abouzeid, and N. Ouerfelli, "Contribution to modelling the effect of temperature on removal of nickel ions by adsorption on nanobentonite," Asian Journal of Chemistry, vol. 30, no. 5, pp. 1147-1156, 2018.

[17] S. Yildiz, "Kinetic and isotherm analysis of $\mathrm{Cu}(\mathrm{II})$ adsorption onto almond shell (Prunus dulcis)," Ecological Chemistry and Engineering S, vol. 24, no. 1, pp. 87-106, 2017.

[18] S.-A. Sajjadi, A. Meknati, E. C. Lima et al., "A novel route for preparation of chemically activated carbon from pistachio wood for highly efficient $\mathrm{Pb}(\mathrm{II})$ sorption," Journal of Environmental Management, vol. 236, pp. 34-44, 2019.

[19] M. Al-Shannag, Z. Al-Qodah, M. Nawasreh, Z. Al-Hamamreh, K. Bani-Melhem, and M. Alkasrawi, "On the performance of Ballota undulata biomass for the removal of cadmium(II) ions from water," Desalination and Water Treatment, vol. 67, pp. 223-230, 2017.

[20] N. A. Rohaizar, N. Hadi, and W. C. Sien, "Removal of Cu ( II ) from water by adsorption on chicken eggshell," International Journal of Engineering and Technology, vol. 13, pp. 40-45, 2013.

[21] Q. Wu, J. Chen, M. Clark, and Y. Yu, “Adsorption of copper to different biogenic oyster shell structures," Applied Surface Science, vol. 311, pp. 264-272, 2014.

[22] D. Lubell, "Are land snail a signature for the MesolithicNeolithic transition," Documenta Praehistorica, vol. 31, pp. 1-24, 2004.

[23] R. Ouafi, Z. Rais, and M. Taleb, "Identification of natural wastes for application in water treatment," Desalination and Water Treatment, vol. 180, pp. 185-192, 2020.

[24] S. K. Bozbaş and Y. Boz, "Low-cost biosorbent: Anadara inaequivalvis shells for removal of $\mathrm{Pb}$ (II) and $\mathrm{Cu}$ (II) from aqueous solution," Process Safety and Environmental Protection, vol. 103, pp. 144-152, 2016.

[25] R. Zhang, J. J. Richardson, A. F. Masters, G. Yun, K. Liang, and T. Maschmeyer, "Effective removal of toxic heavy metal ions from aqueous solution by $\mathrm{CaCO} 3$ microparticles," Water, Air, and Soil Pollution, vol. 229, 2018a.

[26] S. Lagergren, "Zur theorie der sogenannten adsorption geloster stoffe," Zeitschrift für Chemie und Industrie der Kolloide, vol. 24, pp. 1-39, 1898.

[27] G. Blanchard, M. Maunaye, and G. Martin, "Removal of heavy metals from waters by means of natural zeolites," Water Research, vol. 18, no. 12, pp. 1501-1507, 1984.

[28] J. Zeldowitsch, "Über den mechanismus der katalytischen oxydation von CO an MnO2," Acta Physicochim. URSS, vol. 1, pp. 364-449, 1934.

[29] I. Langmuir, "The adsorption of gases on plane surfaces of glass, mica and platinum," Journal of the American Chemical Society, vol. 40, no. 9, pp. 1361-1403, 1918.

[30] H. Freundlich, "Über die Adsorption in Lösungen," Zeitschrift für Physikalische Chemie, vol. 57, pp. 386-470, 1906.

[31] É. C. Lima, M. A. Adebayo, and F. M. Machado, "Kinetic and equilibrium models of adsorption," in Carbon Nanomaterials as Adsorbents for Environmental and Biological Applications, Carbon Nanostructures, C. P. Bergmann and F. M. Machado, Eds., Springer International Publishing, Cham, Switzerland, pp. 33-69, 2015.

[32] H. N. Tran, S.-J. You, A. Hosseini-Bandegharaei, and H.-P. Chao, "Mistakes and inconsistencies regarding adsorption of contaminants from aqueous solutions: a critical review," Water Research, vol. 120, pp. 88-116, 2017.
[33] H. N. Tran, S.-J. You, and H.-P. Chao, "Thermodynamic parameters of cadmium adsorption onto orange peel calculated from various methods: a comparison study," Journal of Environmental Chemical Engineering, vol. 4, no. 3, pp. 2671-2682, 2016.

[34] X. Zhou and X. Zhou, "The unit problem in the thermodynamic calculation of adsorption using the Langmuir equation," Chemical Engineering Communications, vol. 201, no. 11, pp. 1459-1467, 2014.

[35] G. Aditya and A. Hossain, "Valorization of aquaculture waste in removal of cadmium from aqueous solution: optimization by kinetics and ANN analysis," Applied Water Science, vol. 8, no. 2, p. 68, 2018.

[36] H. Hadj Mokhtar, B. Boukoussa, R. Hamacha, A. Bengueddach, and D. El Abed, "CuCO3-CuO nanocomposite as a novel and environmentally friendly catalyst for triazole synthesis," RSC Advances, vol. 5, no. 113, pp. 93438-93446, 2015.

[37] T. Wen, Y. Zhao, T. Zhang et al., "Effect of anions species on copper removal from wastewater by using mechanically activated calcium carbonate," Chemosphere, vol. 230, pp. 127135, 2019.

[38] T. Zhang, T. Wen, Y. Zhao, H. Hu, B. Xiong, and Q. Zhang, "Antibacterial activity of the sediment of copper removal from wastewater by using mechanically activated calcium carbonate," Journal of Cleaner Production, vol. 203, pp. 10191027, 2018b.

[39] Q.-R. Fang, T. A. Makal, M. D. Young, and H.-C. Zhou, "Recent advances in the study of mesoporous metal-organic frameworks," Comments on Inorganic Chemistry, vol. 31, no. 5-6, pp. 165-195, 2010.

[40] P. Lertwattanaruk, N. Makul, and C. Siripattarapravat, "Utilization of ground waste seashells in cement mortars for masonry and plastering," Journal of Environmental Management, vol. 111, pp. 133-141, 2012.

[41] H. T. Van, L. H. Nguyen, V. D. Nguyen et al., "Characteristics and mechanisms of cadmium adsorption onto biogenic aragonite shells-derived biosorbent: batch and column studies," Journal of Environmental Management, vol. 241, pp. 535-548, 2019.

[42] A. P. Lim and A. Z. Aris, "Continuous fixed-bed column study and adsorption modeling: removal of cadmium (II) and lead (II) ions in aqueous solution by dead calcareous skeletons," Biochemical Engineering Journal, vol. 87, pp. 50-61, 2014.

[43] S.-W. Lee, Y.-N. Jang, and J.-C. Kim, "Characteristics of the aragonitic layer in adult oyster shells,Crassostrea gigas: structural study of myostracum including the adductor muscle scar," Evidence-based Complementary and Alternative Medicine, vol. 2011, 10 pages, 2011.

[44] A. Shafiu Kamba, M. Ismail, T. A. Tengku Ibrahim, and Z. A. B. Zakaria, "Synthesis and characterisation of calcium carbonate aragonite nanocrystals from cockle shell powder (Anadara granosa)," Journal of Nanomaterials, vol. 2013, 9 pages, 2013.

[45] S. A. El-Korashy, "Studies on divalent ion uptake of transition metal cations by calcite through crystallization and cation exchange process," Journal of Materials Science, vol. 38, no. 8, pp. 1709-1719, 2003.

[46] M. Mellini and S. Merlino, "Posnjakite: $2 \infty[\mathrm{Cu} 4(\mathrm{OH})$ 6(H2O)O] octahedral sheets in its structure," Zeitschrift für Kristallographie - Crystalline Materials, vol. 149, no. 3-4, pp. 249-257, 1979.

[47] A. H. Zittlau, Q. Shi, J. Boerio-Goates, B. F. Woodfield, and J. Majzlan, "Thermodynamics of the basic copper sulfates 
antlerite, posnjakite, and brochantite," Geochemistry, vol. 73, no. 1, pp. 39-50, 2013.

[48] X.-q. Chen, B. Li, Y. Shen, and J.-Z. Guo, "Facile synthesis of calcite-impregnated hydrochar with high sorption capacity for $\mathrm{Cu}(\mathrm{II})$ from aqueous solution," ACS Omega, vol. 4, no. 12, pp. 15022-15029, 2019.

[49] World Health Organization, Guidelines for Drinking-Water Quality, World Health Organization, Geneva, Switzerland, 4th edition, 2017.

[50] J. López-Luna, L. E. Ramírez-Montes, S. Martinez-Vargas et al., "Linear and nonlinear kinetic and isotherm adsorption models for arsenic removal by manganese ferrite nanoparticles," SN Applied Sciences, vol. 1, no. 8, p. 950, 2019.

[51] R. Slimani, "Biosorption isotherm for of $\mathrm{Cu}$ (II) and $\mathrm{Zn}$ (II) onto calcined limpet shells as a new biosorbent ions from aqueous solutions: comparison of linear and non-linear methods," International Journal of Environmental Monitoring and Analysis, vol. 2, no. 6, p. 48, 2014.

[52] F. Boukhlifi and A. Bencheikh, "Characterization of natural biosorbents used for the depollution of waste water," Annales de Chimie Science des Matriaux, vol. 25, no. 2, pp. 153-160, 2000.

[53] K. Karageorgiou, M. Paschalis, and G. N. Anastassakis, "Removal of phosphate species from solution by adsorption onto calcite used as natural adsorbent," Journal of Hazardous Materials, vol. 139, no. 3, pp. 447-452, 2007.

[54] Y. Du, F. Lian, and L. Zhu, "Biosorption of divalent Pb, Cd and $\mathrm{Zn}$ on aragonite and calcite mollusk shells," Environmental Pollution, vol. 159, no. 7, pp. 1763-1768, 2011.

[55] N. Fiol and I. Villaescusa, "Determination of sorbent point zero charge: usefulness in sorption studies," Environmental Chemistry Letters, vol. 7, no. 1, pp. 79-84, 2009.

[56] A. S. Yusuff, I. I. Olateju, and S. E. Ekanem, "Equilibrium, kinetic and thermodynamic studies of the adsorption of heavy metals from aqueous solution by thermally treated quail eggshell," Journal of Environmental Science and Technology, vol. 10, no. 5, pp. 245-257, 2017.

[57] K. R. Hall, L. C. Eagleton, A. Acrivos, and T. Vermeulen, "Pore- and solid-diffusion kinetics in fixed-bed adsorption under constant-pattern conditions," Industrial \& Engineering Chemistry Fundamentals, vol. 5, no. 2, pp. 212-223, 1966.

[58] H. Asgari, A. G. Odeshi, J. A. Szpunar, and S. Sadighi, "On dynamic deformation behavior of WE43 magnesium alloy sheet under shock loading conditions," Materials \& Design, vol. 63, pp. 552-564, 2014.

[59] P. Saha and S. Chowdhury, "Insight into adsorption thermodynamics," in ThermodynamicsInTech, London, UK, 2011.

[60] J. D. Cuppett, S. E. Duncan, and A. M. Dietrich, "Evaluation of copper speciation and water quality factors that affect aqueous copper tasting response," Chemical Senses, vol. 31, no. 7, pp. 689-697, 2006.

[61] X. Li, Z. Lei, J. Qu, X. Zhou, Z. Li, and Q. Zhang, "Separation of $\mathrm{Cu}$ (II) from $\mathrm{Cd}(\mathrm{II})$ in sulfate solution using $\mathrm{CaCO}_{3}$ and $\mathrm{FeSO}_{4}$ Based on Mechanochemical Activation 2002-2008," RSC Advances, vol. 2017, 2017.

[62] T. Aniyikaiye, T. Oluseyi, J. Odiyo, and J. Edokpayi, "Physicochemical analysis of wastewater discharge from selected paint industries in Lagos, Nigeria," International Journal of Environmental Research and Public Health, vol. 16, no. 7, p. 1235, 2019.

[63] World Health Organization, A Compendium of Standards for Wastewater Reuse in the Eastern Mediterranean Region, World Health Organization, Geneva, Switzerland, 2006.
[64] F. Bakhtiari and E. Darezereshki, "One-step synthesis of tenorite $(\mathrm{CuO})$ nano-particles from $\mathrm{Cu} 4(\mathrm{SO} 4)(\mathrm{OH}) 6$ by direct thermal-decomposition method," Materials Letters, vol. 65, no. 2, pp. 171-174, 2011.

[65] S. Alikhanzadeh-Arani and M. Salavati-Niasari, "Synthesize and characterization of $\mathrm{Ca}_{2} \mathrm{CuO}_{3}$ nanostructures via a modified sol-gel method assisted by hydrothermal process," Journal of Cluster Science, vol. 23, no. 4, pp. 1069-1080, 2012.

[66] S. Niju, F. R. Raj, C. Anushya, and M. Balajii, "Optimization of acid catalyzed esterification and mixed metal oxide catalyzed transesterification for biodiesel production from Moringa oleifera oil," Green Processing and Synthesis, vol. 8, no. 1, pp. 756-775, 2019.

[67] J. K. Sharma, M. S. Akhtar, S. Ameen, P. Srivastava, and G. Singh, "Green synthesis of $\mathrm{CuO}$ nanoparticles with leaf extract of Calotropis gigantea and its dye-sensitized solar cells applications," Journal of Alloys and Compounds, vol. 632, pp. 321-325, 2015.

[68] S. Soltani Nezhad, M. Rabbani Khorasgani, G. Emtiazi, M. M. Yaghoobi, and S. Shakeri, "Isolation of copper oxide $(\mathrm{CuO})$ nanoparticles resistant Pseudomonas strains from soil and investigation on possible mechanism for resistance," World Journal of Microbiology and Biotechnology, vol. 30, no. 3, pp. 809-817, 2014.

[69] C. Angelé-Martínez, K. V. T. Nguyen, F. S. Ameer, J. N. Anker, and J. L. Brumaghim, "Reactive oxygen species generation by copper(II) oxide nanoparticles determined by DNA damage assays and EPR spectroscopy," Nanotoxicology, vol. 11, no. 2, pp. 278-288, 2017.

[70] D. Chudobova, K. Cihalova, P. Kopel et al., "Complexes of metal-based nanoparticles with chitosan suppressing the risk of Staphylococcus aureus and Escherichia coli infections," in Nanotechnology in Diagnosis, Treatment and Prophylaxis of Infectious Diseases, pp. 217-232, Elsevier, Amsterdam, Netherlands, 2015.

[71] L. M. Correia, R. M. A. Saboya, N. de Sousa Campelo et al., "Characterization of calcium oxide catalysts from natural sources and their application in the transesterification of sunflower oil," Bioresource Technology, vol. 151, pp. 207-213, 2014.

[72] D.-W. Lee, Y.-M. Park, and K.-Y. Lee, "Heterogeneous base catalysts for transesterification in biodiesel synthesis," $\mathrm{Ca}$ talysis Surveys from Asia, vol. 13, no. 2, pp. 63-77, 2009.

[73] K. H. Mo, U. J. Alengaram, M. Z. Jumaat, S. C. Lee, W. I. Goh, and C. W. Yuen, "Recycling of seashell waste in concrete: a review," Construction and Building Materials, vol. 162, pp. 751-764, 2018.

[74] F. Chang, Q. Zhou, H. Pan et al., "Solid mixed-metal-oxide catalysts for biodiesel production: a review," Energy Technology, vol. 2, no. 11, pp. 865-873, 2014.

[75] H. V. Lee, J. C. Juan, T. Y. Yun Hin, and H. C. Ong, "Environment-friendly heterogeneous alkaline-Based mixed metal oxide catalysts for biodiesel production," Energies, vol. 9, 2016.

[76] M. Petrović, T. Šoštarić, M. Stojanović et al., "Mechanism of adsorption of $\mathrm{Cu} 2+$ and $\mathrm{Zn} 2+$ on the corn silk (Zea mays L.)," Ecological Engineering, vol. 99, pp. 83-90, 2017.

[77] T. Musso, M. Parolo, and G. Pettinari, " $\mathrm{pH}$, ionic strength, and ion competition effect on $\mathrm{Cu}(\mathrm{II})$ and $\mathrm{Ni}(\mathrm{II})$ sorption by a Na-bentonite used as liner material," Polish Journal of Environmental Studies, vol. 28, no. 4, pp. 2299-2309, 2019.

[78] M. Petrovic, T. Sostaric, L. Pezo et al., "Usefulness of ANNbased model for copper removal from aqueous solutions using agro industrial waste materials," Chemical Industry and 
Chemical Engineering Quarterly, vol. 21, no. 2, pp. 249-259, 2015.

[79] M. S. Rahman and M. R. Islam, "Effects of $\mathrm{pH}$ on isotherms modeling for $\mathrm{Cu}(\mathrm{II})$ ions adsorption using maple wood sawdust," Chemical Engineering Journal, vol. 149, no. 1-3, pp. 273-280, 2009.

[80] R. Ouafi, A. Omor, Y. Gaga, M. Akhazzane, M. Taleb, and Z. Rais, "Pine cones powder for the adsorptive removal of copper ions from water," Chemical Industry and Chemical Engineering Quarterly, vol. 53, p. 1, 2021. 